NBER WORKING PAPER SERIES

\title{
BOARDING A SINKING SHIP? AN INVESTIGATION OF JOB APPLICATIONS TO DISTRESSED FIRMS
}

\author{
Jennifer Brown \\ David A. Matsa \\ Working Paper 18208 \\ http://www.nber.org/papers/w18208
NATIONAL BUREAU OF ECONOMIC RESEARCH
1050 Massachusetts Avenue
Cambridge, MA 02138
July 2012

\begin{abstract}
We are grateful to the research and data management teams at the company that provided the data for this research. For helpful comments, we also thank Emek Basker, Bo Becker, Effi Benmelech, Meghan Busse, Jason Faberman, Craig Furfine, Craig Garthwaite, Todd Gormley, Edith Hotchkiss, Hyunseob Kim, Danielle Li, Brian Melzer, Dylan Minor, Hernan Ortiz-Molina, Josh Rauh, Antoinette Schoar, Aaron Sojourner, Chris Stanton and Amir Sufi, as well as seminar participants at the Bank of Portugal, HEC Montreal, MIT, Michigan State University, National University of Singapore, Shanghai University of Finance and Economics, Tsinghua University, University of Alberta, University of British Columbia, University of Georgia, University of Maryland, University of North Carolina, University of Notre Dame, University of Southern California, University of Toronto, University of Utah, Federal Reserve Bank of Chicago, American Finance Association Meeting, Bank of Portugal Conference on the Labor Market, CSEF Conference on Finance and Labor, European Winter Finance Conference, LMU Munich Workshop on Natural Experiments and Controlled Field Studies, NBER Corporate Finance Program, University of Michigan Mitsui Finance Symposium, University of Tokyo and RIETI International Workshop on Personnel Economics, Western Finance Association Meeting, and Utah Winter Business Economics Conference. The views expressed herein are those of the authors and do not necessarily reflect the views of the National Bureau of Economic Research.
\end{abstract}

NBER working papers are circulated for discussion and comment purposes. They have not been peerreviewed or been subject to the review by the NBER Board of Directors that accompanies official NBER publications.

(C) 2012 by Jennifer Brown and David A. Matsa. All rights reserved. Short sections of text, not to exceed two paragraphs, may be quoted without explicit permission provided that full credit, including $(\mathrm{C}$ notice, is given to the source. 
Boarding a Sinking Ship? An Investigation of Job Applications to Distressed Firms Jennifer Brown and David A. Matsa

NBER Working Paper No. 18208

July 2012, Revised May 2015

JEL No. G20,G32,G33,J64,M5

\begin{abstract}
$\underline{\text { ABSTRACT }}$
We use novel data from a leading online job search platform to examine the impact of corporate distress on firms' ability to attract job applicants. Survey responses suggest that job seekers accurately perceive firms' financial condition, as measured by companies' credit default swap prices and accounting data. Analyzing responses to job postings by major financial firms during the Great Recession, we find that an increase in an employer's distress results in fewer and lower quality applicants. These effects are particularly evident when the social safety net provides workers with weak protection against unemployment and for positions requiring a college education.
\end{abstract}

\author{
Jennifer Brown \\ Department of Management and Strategy \\ Kellogg School of Management \\ Northwestern University \\ 2001 Sheridan Road \\ Evanston, IL 60208 \\ and NBER \\ jen-brown@kellogg.northwestern.edu \\ David A. Matsa \\ Kellogg School of Management \\ Northwestern University \\ 2001 Sheridan Road \\ Evanston, IL 60208 \\ and NBER \\ dmatsa@kellogg.northwestern.edu
}




\section{Introduction}

A company's financial condition has far-reaching effects on the firm, including on its ability to attract and retain human capital. Corporate distress can lead current employees to search for more stable positions and new recruits to focus their searches elsewhere. Concerns about short-run solvency strain a firm's reputation for treating employees fairly (Maksimovic and Titman 1991), and corporate distress often leads firms to pay lower wages (Graham et al. 2013) and to downsize their workforce. Average employment decreases by $10 \%$ around a bond covenant violation (Falato and Liang 2012), by 27\% around a bond default (Agrawal and Matsa 2013), and by $50 \%$ or more around a bankruptcy filing (Hotchkiss 1995).

Job loss can be extremely costly for workers and, as a result, workers are likely to avoid distressed firms. ${ }^{1}$ Unless distressed firms can offer a sufficient compensating wage premium, they may have difficulty recruiting new talent, particularly for positions that require firm-specific investments. Although such costs of distress feature prominently in theoretical explanations of firms' capital structure decisions (Titman 1984; Berk, Stanton, and Zechner 2010), their empirical relevance is less clear.

Empirical evidence is sparse, in part, because it is challenging to separately identify the effects of corporate distress on demand and supply in the market for labor. Distress often reduces a firm's scale and labor demand, while also making the firm less attractive to workers and reducing labor supply. With data only on employment or wages, it is impossible to separate these channels empirically. This paper exploits several novel datasets from a large online job search

\footnotetext{
${ }^{1}$ Workers face reductions in consumption during unemployment and less stability in earnings and employment, even ten years later (Gibbons and Katz 1991; Jacobson, LaLonde, and Sullivan 1993; Gruber 1997; Sullivan and von Wachter 2009). With job displacement also leading to worse health outcomes, higher mortality, lower achievement by children, and other adverse consequences (see Davis and von Wachter 2011 for a survey), even the prospect of job insecurity imposes sizeable psychological costs on workers (Sverke and Hellgren 2002).
} 
platform to overcome this identification challenge. ${ }^{2}$ With microdata on job applications, we hold demand fixed and examine how the supply of workers to specific jobs at individual firms is affected by firms' financial condition.

We first examine survey responses of job seekers on the online platform to evaluate job seekers' perceptions of firms' financial condition. We match job seekers' assessments of 145 firms between October 2008 and March 2010 with indicators of financial strength, including daily credit default swap (CDS) prices. Across the various measures, we consistently find that job seekers' perceptions are highly positively correlated with firms' true financial condition.

Our second analysis examines whether applicants act on these perceptions. We exploit a second proprietary dataset that describes all of the jobs posted by forty high-profile financial services firms to the job search platform between April 2008 and December 2009. ${ }^{3}$ Similar to Holzer, Katz, and Krueger (1991), we examine the volume of applications to open positions as a measure of workers' interest in these jobs. We match the application data with firms' CDS prices to assess the relationship between firm's financial condition and workers' willingness to apply.

During the Great Recession, corporate financial conditions varied substantially both between and within financial firms over time. Our identification strategy exploits these changes. The richness of the data allows us to develop a compelling counterfactual in our analysis. We compare job seekers' interest in a given posting to their interest in other postings for the same type of job in the same geographic area and the same month, and we test whether the firm's

\footnotetext{
${ }^{2}$ We were provided the data under a nondisclosure agreement, which restricts us from identifying the online platform. This agreement places no constraints on the conclusions of the analysis.

${ }^{3}$ Our data provider requested that we restrict the application sample to one industry and a limited period of time. We chose the financial sector and this 21-month period because the application data have strong coverage, many firms have traded CDS, and firms experienced various degrees of distress in this periodsome sample firms experienced extreme distress, some less extreme, and some not at all. The survey results show that potential applicants in other industries are aware of firms' financial conditions as well.
} 
credit default risk at the time of the posting is related to the number of applications. ${ }^{4}$ The detailed fixed effects rule out many possible alternative interpretations, such as a decline in the social status of finance jobs or changes in unobserved local industry- and occupation-specific investment opportunities or labor market conditions. All of our analyses also control for firm fixed effects so that we are measuring only time-varying relative differences in the supply of labor to each employer.

We find that firms attract significantly fewer applications per job opening during periods of corporate distress. On average, a 1,000 basis point increase in a firm's CDS price is associated with about $20 \%$ fewer applications to a given position. ${ }^{5}$ The results are not driven by outliers and are robust to alternative measures of firms' financial position. The reduction in applications occurs despite the fact that job seekers typically search more broadly and submit more applications in tight labor market conditions (Kuhnen 2011). Given the low cost of submitting an online application to these jobs, we would expect to find even larger effects on potential applicants' propensity to accept a job offer at a distressed firm. ${ }^{6}$

Analyses of potential mechanisms confirm that the decline in applications cannot be fully explained by shifts in labor demand. We find no evidence that positions that firms post during periods of distress draw from smaller pools of potential applicants or pay lower salaries. If anything, advertised salaries increase when a firm is in distress.

Heterogeneity in the effect along two dimensions further supports the interpretation that

\footnotetext{
${ }^{4}$ Of course, we are not suggesting that job seekers track individual firms' actual CDS prices over time. After establishing that job seekers' perceptions of firms' financial stability are correlated with CDS prices, we use these prices to proxy for firms' (actual and perceived) overall financial condition.

5 A 1,000 basis point increase in a firm's CDS price is large but not unusual during our sample period. The increase is associated with a five-year cumulative default rate increase of about 17 percentage points (see footnote 21). Among all firms in the financial sector with total assets greater than $\$ 25$ billion for which CDS prices are available, 20\% experienced CDS price swings exceeding 1,000 basis points during the Great Recession.

${ }^{6}$ Our data provider does not observe who is interviewed or hired for the open positions.
} 
firms' distress affects labor supply — that is, holding fixed other job-specific and labor marketspecific characteristics, a worker prefers to work for a firm that is in a stronger financial position. First, we exploit state-level variation in unemployment insurance (UI) and find that workers are less sensitive to potential employers' distress in locations in which unemployment costs are lessened by a stronger social safety net. Second, we find that large upfront costs make job seekers reluctant to apply to distressed firms. Specifically, we find that distressed firms receive a lower proportion of job applications from out-of-state applicants-individuals for whom new employment is typically particularly costly and disruptive.

The negative effect of corporate distress on labor supply has potential implications for distressed firms' human capital accumulation and retention. We find that applicants' average quality, as measured by the average earnings and education of their ZIP codes, declines with firms' distress. Furthermore, the estimated sensitivity of applications to distressed companies is most pronounced and consistent for jobs with high educational requirements. These results align with Topel (1991) and Topel and Ward's (1992) findings that the costs of unemployment are higher for workers who have been in their jobs longer and that job tenure is positively correlated with education. Connolly and Gottchalk (2006) argue that highly educated workers bear particularly large unemployment costs because jobs that require substantial education also often require firm-specific investment by the employee. It is also possible that more highly educated workers are more attuned to changes in firms' financial condition.

Although our application results apply directly to distressed firms' challenges in recruiting new employees, firm characteristics that attract new workers are likely similar to those that encourage existing workers to remain with the firm. We find that distressed firms actively try to hire new employees despite large, concomitant overall declines in employment. Current 
workers are likely reluctant to stay with a distressed firm because of diminished job security and other outcomes of corporate distress.

It is impossible to definitively distinguish the effects of economic and financial distressthat is, whether job seekers are responding strictly to firms' deteriorating operating performance or also to the firms' financial structure. Nevertheless, it is likely that corporate debt amplifies workers' responses to operating shortfalls. First, we find greater declines in the volume of applications during the downturn among firms with more constraining capital structures-firms with greater leverage and whose debt has shorter maturity and more covenants. Second, we find that the volume of applications is sensitive to firms' financial distress (CDS price) even after controlling for the firms' operating performance (ROA). And third, we find that unemployment insurance mitigates the reductions in labor supply, suggesting that these reductions are related, at least in part, to concerns about job security. Even if the job insecurity in our study results from exclusively economic distress, we would expect labor supply to respond similarly to financial distress, which is also known to increase the likelihood of downsizing and job insecurity (Falato and Liang 2012; Agrawal and Matsa 2013). ${ }^{7}$

Firms can avoid financial distress and create value by choosing more conservative financial policies. Consistent with this idea, recent evidence suggests that firms increase leverage when workers' displacement costs decline. Agrawal and Matsa (2013) find that increases in legally mandated unemployment benefits lead to increases in corporate leverage. Kim (2012)

\footnotetext{
${ }^{7}$ In addition to the labor market effects examined in this paper, distress may affect real asset prices (Pulvino 1998), competitors' collateral values (Benmelech and Bergman 2011), and how firms compete in product markets, including entry (Chevalier 1995a), exit (Kovenock and Phillips 1997; Zingales 1998), pricing (Chevalier 1995b; Phillips 1995; Chevalier and Scharfstein 1996), and product quality (Rose 1990; Borenstein and Rose 2003; Matsa 2011; Phillips and Sertsios 2013). Most recently, Hortascu et al. (2013) find that prices for used automobiles respond to high-frequency fluctuations in manufacturers' distress. They estimate that a 1,000 basis point increase in the CDS price decreases the price of a used car by $\$ 68$ (or $0.5 \%$ ); the labor market impacts appear be much larger, as we find that both the volume of applications drops and wages increase by about $20 \%$.
} 
exploits new manufacturing plant openings to argue that firms increase financial leverage when their workers have additional job opportunities. Other recent papers also integrate labor economics and finance and focus on the use of leverage as a strategic input in the bargaining process between workers and firms (e.g., Matsa 2010; Chen, Kacperczyk, and Ortiz-Molina 2011; Benmelech, Bergman, and Enriquez 2012).

Our findings also advance the labor economics literature on compensating wage differentials for unemployment risk. ${ }^{8}$ We find that, when a firm's CDS price is 1,000 basis points higher, it posts 16 to $18 \log$ point higher wages for a given open position. This sizeable differential underscores our overall conclusion that a business's financial condition has meaningful consequences for the recruitment and retention of human capital. Moreover, this article is part of a renewed interest among labor economists in the importance of firms for workers' labor market experiences (Card 2011).

The remainder of the paper is organized as follows. In Section 2, we examine job seekers' self-reported perceptions of firms' financial condition. In Section 3, we analyze the relationship between firms' financial success and the volume of applications attracted to open positions. In Section 4, we consider competing explanations for the relationship, and we explore potential implications for firms' accumulation of human capital in Section 5. We conclude in Section 6.

\footnotetext{
${ }^{8}$ Empirical estimates of compensating wage differentials are typically based on worker surveys in which unobserved worker characteristics, including their productivity, could be correlated with unemployment risk (e.g., Abowd and Ashenfelter 1981; Topel 1984; Fishback 1998; Averett, Bodenhorn, and Staisiunas 2005). Using industry-level volatility to instrument for unemployment risk, Peters and Wagner (2013) find that turnover risk is associated with higher CEO compensation.
} 


\section{Do job seekers accurately perceive firms' financial condition?}

To study the accuracy of job seekers' perceptions of companies' financial positions, we analyze data from a set of proprietary surveys. Eighty-one surveys were conducted by a large online job search platform between October 2008 and March 2010. In total, the platform has millions of active users every month, more than half of whom are college graduates.

A typical survey asked respondents to consider four firms that are labor market competitors in a given industry. The questions asked job seekers to indicate their perception of firms' performance on several dimensions, including salary, training, reputation, workforce diversity, and company financials. Answers were given on a five-point scale, where "1" indicates strong disagreement and " 5 " indicates strong agreement with, for example, the statement that a given firm is a "financially strong organization." Respondents who answered that they were "not sure" (or, assumedly, unfamiliar with the firm in question) are excluded from the data used in our analysis. ${ }^{9}$ In the analysis that follows, we examine averages of these scores at the firm-survey level. $^{10}$

To assess whether job seekers' perceptions of firms' financial condition reflect companies' actual performance, we matched the survey responses to daily credit default swap (CDS) prices. CDS prices provide a measure of individual firms' financial condition. CDS are

\footnotetext{
9 On average, approximately $38 \%$ of respondents indicated that they were unsure about the firms' financial condition ( $26 \%$ for financial services firms). The "unsure" rates were similar for questions about companies' reputations and higher for questions about corporate culture, compensation, and training. Unawareness about firms' financial condition appears to be unrelated to distress - the correlation of CDS price and the percentage of respondents who are unsure is small and not statistically significant $(-0.02$; $p=0.84)$.

${ }^{10}$ Some scores are correlated across questions - this is not a surprise since many dimensions of firm performance and job features are correlated in practice. For example, because financial distress can strain a firm's ability to treat workers fairly and to honor implicit contracts (Maksimovic and Titman 1991), it is unsurprising that the scores for reputation and company financials are correlated (0.77). As one would expect, other scores are less correlated; for example, the correlation between financials and workforce diversity is only 0.36 . In any case, our analysis confirms that job seekers' perceptions are indeed significantly related to firms' actual financial condition.
} 
financial contracts that pay off when a firm defaults on a specific existing debt obligation. A firm's debt holders can purchase CDS as protection against a bad financial event; however, unlike traditional insurance, CDS buyers need not hold any of the firm's actual debt. CDS prices are typically denoted in basis points of the insured value and increase with the probability of default — that is, CDS prices are higher for riskier companies. Consider a simple example in which the CDS price for a firm's debt is 150 basis points or $1.5 \%$. An investor can buy $\$ 1$ million worth of CDS protection from a large bank for an annualized premium of $\$ 15,000$. If the firm were to default on its entire debt, then the bank would effectively pay $\$ 1$ million to the CDS buyer. ${ }^{11}$

In broad terms, the CDS prices that we examine reflect the likelihood that firms fall into severe financial trouble within five years. Throughout our analysis, we use prices, obtained from Bloomberg, for five-year CDS contracts covering firms' senior bonds. These CDS prices are available on a daily basis. We also compare survey respondents' assessments to quarterly accounting data from Compustat.

Table 1 reports summary statistics of the survey sample. As described in Panel A, the surveys collectively cover 145 unique firms for which CDS prices or Compustat data are available. Some firms are included in multiple surveys, yielding 194 total firm observations, 126 of which have CDS prices available. On average, about 150 survey responses underlie each firm observation. The average survey financial score is 3.3 on the five-point scale.

The surveys mostly cover large firms. Panel B of Table 1 describes the survey firms using data from the Compustat quarterly file for the first quarter of 2008 (prior to start of the surveys). Among survey firms with information in Compustat, the average market capitalization

\footnotetext{
${ }^{11}$ When a credit event occurs, CDS contracts are typically settled by a credit event auction in which participants have the choice between cash and physical settlement.
} 
was $\$ 32$ billion. The average return on assets was $2 \%$, sales growth was $11 \%$, and the market-tobook ratio was 1.65 . Although the typical survey firm had modest financial leverage — total debt averaged $29 \%$ of book assets - a minority were highly leveraged with $17 \%$ having more than $50 \%$ leverage. ${ }^{12}$ Panel $\mathrm{C}$ of Table 1 reports the firms' distribution across industries. The two most represented industries are manufacturing and finance with about thirty firms each. Overall, the sample includes large firms that were performing moderately well before the crisis.

Figure 1 compares CDS prices to job seekers' average rating of the financial condition of firms included in the surveys. ${ }^{13}$ Panel A presents results for all firms for which data were available. The figure is striking - when the CDS price is high, indicating that a firm has a higher risk of defaulting on its credit obligations, job seekers perceive the firm's weak financial position.

The recent economic crisis, which began in late 2007 , provides us with an opportunity to study the labor-related costs of firms' distress over a period in which many firms were experiencing dramatic changes in their financial condition. The rise and fall of firms in the financial industry received widespread attention - the condition of both weak and strong financial services firms was likely to be particularly salient for job seekers in 2008 and 2009.

Thirty firms in the financial services industry (including banks, lenders, investment firms, and insurance companies) are among the firms covered in the surveys. Panel B of Figure 1 plots CDS prices and survey financial scores for the eighteen of these firms for which CDS prices are available. Similar to the plot with all firms, job seekers' perceptions of firms' financial condition appear to be associated with the firms' actual financial positions.

\footnotetext{
12 These summary statistics are not winsorized. Winsorizing these variables has little effect on our estimates.

${ }^{13}$ To conceal firms' identities, Figures 1 and 2 only include firms with CDS prices below 1,000 basis points. The regression analyses include all firm observations.
} 
Regression analysis, controlling for several other factors that might influence survey scores, provides further evidence of a relationship between job seekers' perceptions and firms' actual financial position. Table 2 reports these regression results; Panel A presents results for all firms in the surveys for which CDS prices are available and Panel B focuses on firms in the financial services industry. In various specifications, we include controls for firms' industry (using three-digit NAICS codes) and survey quarter fixed effects.

In all of the regressions, the coefficient on CDS price is negative and statistically significant $(p<0.01)$. In general, a one-standard-deviation increase in the CDS price reduces the average survey score by 0.17 to 0.19 (approximately 0.45 to 0.51 of a standard deviation). Job seekers are unlikely to be tracking CDS prices in a literal sense; more likely, their perceptions are based on indirect sources, such as media reports and word of mouth. Whatever forms their perceptions, our results suggest that they accurately reflect the overall financial condition of individual firms.

In addition to CDS prices, other financial measures also provide compelling evidence that job seekers perceive differences in firms' condition. Using quarterly financial data from S\&P's Compustat, we generate several variables to represent aspects of companies' financial strengths or weaknesses: quarterly return on assets reflects a firm's current profitability; sales growth (over last year, same quarter) reflects a firm's past performance; and the market-to-book ratio reflects a firm's future prospects. Because recent performance is likely the most salient for job seekers, we examine the conditional correlation of the mean survey response and a firm's performance in the previous quarter.

The results, reported in Table 3, confirm that job seekers' perceptions of firms' financial strength are highly correlated with firms' actual performance. Panel A of Table 3 reports results 
for the full sample. Results in column 3.A indicate that a one-standard-deviation increase in quarterly return on assets is associated with a 0.1 point increase in the average survey score (approximately a quarter of a standard deviation; $p<0.01$ ). Similarly, a one-standard-deviation increase in sales growth (column 3.B) or the market-to-book ratio (column 3.C) is linked to a 0.1 point higher survey score ( $p<0.10$ and $p<0.01$, respectively). In Panel B of Table 3 , we restrict the survey sample to ratings of financial services firms. Among these firms, a one-standarddeviation increase in quarterly return on assets is associated with a 0.4 point improvement in the survey score (nearly a standard deviation; $p<0.01$; column 3.E) ${ }^{14}$ As reported in columns 3.F and 3.G, a one-standard-deviation increase in sales growth or the market-to-book ratio is associated with an improvement of approximately 0.1 and 0.2 survey points (approximately a quarter and a half of a standard deviation; $p<0.05$ and $p<0.01$, respectively). Overall, the patterns in Table 3 provide further evidence that job seekers' assessments reflect firms' actual financial position. ${ }^{15}$

A final test suggests that job seekers perceive firms' economic and financial distress. In columns 3.D and 3.H, we report regressions that relate firms' financial scores with both their return on assets and their CDS price. The results show both relationships to be statistically significant. Even after controlling for a firm's operating performance, job seekers' rating of the company's financial strength is sensitive to the firm's likelihood of defaulting on its debt obligations. The sensitivity declines when we control for operating performance (see Table 2) but remains sizeable and statistically significant $(p<0.01)$. In both samples, after conditioning

\footnotetext{
${ }^{14}$ For the sample of financial services firms, the standard deviation in the second quarter of 2008 is $1.56 \%$ for return on assets, $20.28 \%$ for sales growth, and 0.79 for the market-to-book ratio. The difference in the coefficient estimates on return on assets in Panels A and B reflects the differences in the magnitude and the variance of the measure between the two samples.

${ }^{15}$ The magnitude and statistical significance of the results in Tables 2 and 3 are very similar when the regression coefficients are weighted by the number of survey respondents.
} 
on ROA, a one-standard-deviation increase in the CDS prices reduces the average survey score by 0.16 to 0.17 points ( 0.42 to 0.45 of a standard deviation).

\section{Does firms' financial condition affect job seekers' application behavior?}

The surveys analyzed above suggest that job seekers' perceptions are attuned to firms' financial condition. But do these perceptions affect the firms' appeal to potential applicants? We next examine how employers' financial condition affects job seekers' choices of where to submit applications. We ask: do distressed firms attract fewer applications to open positions?

Our analysis focuses on firms in the financial services industry during the volatile months between April 2008 and December 2009. Variation over this time period allows us to identify the relationship between firms' financial condition and their ability to attract employees. Figure 2 presents daily CDS prices for 78 financial services firms from 2008 to $2010 .{ }^{16}$ The solid line represents the median CDS price, and the dashed lines represent the $25^{\text {th }}$ and $75^{\text {th }}$ percentile prices, respectively. Some firms fared relatively well over this period- the $25^{\text {th }}$ percentile of the CDS price appears relatively stable over time. Other firms struggled, however, as suggested by the dramatic change in the $75^{\text {th }}$ percentile CDS price, and some firms suffered near collapse.

In the analysis that follows, we restrict our sample to the forty large financial firms with total assets exceeding $\$ 25$ billion and for which both job applications data and CDS prices are available. ${ }^{17}$ The job listing and application data are from the same large online job search platform. This proprietary dataset includes job postings for some of the highest-profile financial services firms in the United States—indeed, most of the firms are household names.

\footnotetext{
${ }^{16}$ These 78 firms are all of the firms in the financial sector with total assets greater than $\$ 25$ billion for which CDS prices are available.

${ }^{17}$ See footnote 3 for a discussion of the constraints that led us to choose this sample. The sample's construction limits the inferences we can make about small firms. .
} 
The platform allows firms to post job listings and job seekers to apply to these positions. The platform earns revenues from companies posting positions and from advertising; job seekers use the platform for free. All job listings include the firm's identity and the job's title and location. Firms may also choose to describe the job tasks, educational requirements, compensation, and other benefits. Job seekers can browse job categories-filtering by location, educational requirements, and job characteristics — or search the platform using key words. Firms cannot pay to improve their jobs' placement in these search results.

Summary statistics are reported in Table 4. The sample includes data for 96,065 jobs posted by the forty firms described above between April 2008 and December 2009. The postings include a wide range of positions, including jobs in retail branches (e.g., tellers, account executives, and financial advisors) and back-office jobs (e.g., telephone bankers, financial analysts, software engineers, and administrative assistants). Figure 3 shows the geographic distribution of job postings, which are spread across all fifty U.S. states roughly in proportion to population. ${ }^{18}$ On average, firms posted approximately 2,400 jobs during this 91 -week period; the median firm posted roughly 660 jobs. Applications were thick - an average firm attracted 138,646 applications over the study period, and the average job posting received 57.7 applications (median 28). ${ }^{19}$

We collected CDS prices for the forty firms in the sample. Over all of the postings, CDS prices averaged 237 basis points (median 156). As shown in Figure 2, however, CDS prices varied considerably, both within and between firms over the study period. An average firm

\footnotetext{
${ }^{18}$ Our findings are not limited to large states; for example, we obtain similar estimates when we exclude all states that comprise more than four percent of the sample (California, Florida, Illinois, New York, and Texas).

${ }^{19}$ We do not observe job postings to which no one applied. If firms' distress decreases the number of applications (as our later analysis suggests), then missing these observations may lead us to understate this relationship.
} 
posted jobs in $70 \%$ of the weeks in the period of study; conditional on posting any job in a given week, firms averaged nearly 38 listings per week (median 14).

Figure 4 plots the total number of jobs posted each month by the forty firms in our sample and these firms' median CDS price. There is a marked decline in job postings from the end of 2008 to mid-2009, the time period over which median CDS prices were relatively high. In the regression analysis that follows, we control for these aggregate patterns using month fixed effects.

To explore the impact of corporate distress on firms' appeal to workers, we examine the relationship between firms' default risk and the volume of applications that they attract. When applications are costly, applications rates reflect the attractiveness of the job (Montgomery 1991; Lang 1991). Firms also care directly about the volume of applications because they cannot always hire their most preferred applicant. For example, because individuals can simultaneously apply for multiple positions and receive multiple offers, many applicants may have already accepted other positions by the time the firm is ready to make offers (Lang 1991).

We start by examining the number of applications firms received in October 2008, the month after Lehman Brothers collapsed. Figure 5 depicts the cross-sectional relationship between the number of applications per job posting and firms' CDS price. To avoid identifying specific firms, we plot the predicted number of applications as a quadratic function of the CDS price. Firms with higher CDS prices receive fewer applications per posting — whereas a firm with a CDS price of 100 basis points receives approximately 65 applications per position, a firm with a CDS of price of 1,000 basis points receives fewer than 45 .

Figure 5 shows a stark pattern; but without any controls and with only a single crosssection, we cannot distinguish whether the relationship is attributable to the company's financial 
position or to other firm characteristics. To address these concerns, we turn to multivariate regression analysis on the full panel—using variation over time and across firms, we capture the impact of individual firms' distress on job seekers' behavior, while controlling for other firm-, time-, location-, and job-specific factors.

In these regressions, the unit of observation is a unique job posting, and the dependent variable is the natural log of the number of applications. We use a firm's average CDS price for the calendar month in which the job was first posted. ${ }^{20}$ To make the tables easier to read, the CDS price variable is denoted in decimal form (i.e., 10,000 basis points). Standard errors are clustered at the firm level to account for correlation across jobs posted by the same company.

\subsection{Baseline results}

Table 5 presents results from baseline regressions that use various sets of controls. The specification reported in column 5.A controls for firm and month fixed effects. The firm fixed effects account for any time-invariant differences between firms, such as industry, year of incorporation, and broad market positioning. The month fixed effects account for the changing aggregate economic conditions during the financial crisis; for example, the controls sweep out the aggregate patterns illustrated in Figure 4. The results suggest that a 1,000 basis point increase in the CDS price is associated with a nearly $20 \log$ point decline in the number of applications per posting $(p<0.05) .{ }^{21}$ To account for geographic variation in job opportunities and changes across states over time, column 5.B includes state fixed effects and column 5.C includes a

\footnotetext{
${ }^{20}$ Job postings are typically open to potential applicants for thirty days.

${ }^{21}$ For context, note that the CDS price difference for BBB and B rating classes was approximately 1,000 basis points in 2002 (Daniels and Jenson 2005). Using data from 1971 to 2006, Altman and Ramayanam (2007) report the five-year cumulative default rates for BBB and B rated corporate bonds as $6.6 \%$ and $23.2 \%$, respectively. Together, this suggests that a 1,000 basis point increase in the CDS price-moving from a $\mathrm{BBB}$ to $\mathrm{B}$ rating - is associated with a five-year cumulative default rate increase of 16.6 percentage points (or approximately 3.3 percentage points per year).
} 
separate state fixed effect for every month in the sample period. The state fixed effects are assigned based on where the specific job is located, not where the firm is headquartered or incorporated. The coefficients on CDS price are similar in these specifications and suggest that a 1,000 basis point increase in the CDS price is associated with a 17 to $18 \log$ point drop in applications $(p<0.05$ and $p<0.01$, respectively).

Even with the firm and state-month controls, it is possible that there is variation over time in the characteristics of the jobs posted by a given firm. This could bias the results if any changes in job characteristics were correlated with CDS prices. For example, administrative and clerical jobs always tend to receive more applications than do accounting jobs; one might ask: are distressed firms relatively more likely to post accounting jobs when CDS prices deteriorate? To evaluate this possibility, we exploit a classification provided by the online platform. Posted jobs are assigned up to four of nineteen job types. ${ }^{22}$ Examples of job types include administrative and clerical, sales, professional services, finance, and customer service.

Column 5.D presents results that include indicator variables for each of the nineteen classification codes. The coefficient on CDS price is virtually unchanged-a 1,000 basis point increase in the CDS price is associated with a $17 \log$ point decline in applications $(p<0.01)$. In column 5.E, we allow for even finer heterogeneity in job types by including the interactions between job classifications for positions that fall into multiple job categories. For example, we separately control for customer service jobs in banking and customer service jobs in insurance. In total, this amounts to 679 unique detailed job classifications. The coefficient on CDS price is again negative and statistically significant - a 1,000 basis point increase in the CDS price is associated with a $13 \log$ point decline in applications $(p<0.01)$.

\footnotetext{
${ }^{22}$ The classification includes eighteen named categories. Any job type represented in less than $2 \%$ of job postings was coded as the nineteenth category, "Other".
} 
In a final specification, we allow the impact of these 679 detailed job types to vary by state-month. With these additional interactions, the specification identifies the relationship between the CDS price and the volume of applications within specific labor markets (i.e., for a particular detailed job type in a given state during a single month). This specification accounts for the possibility that, for example, distressed firms are located in geographic-industry sectors with high unemployment, which could bias our estimates upward (away from finding a reduction in applications). The estimated CDS coefficient is again statistically significant and suggests that a 1,000 basis point increase in the CDS price is associated with a nearly $24 \log$ point decrease in the number of applications $(p<0.01)$. The larger coefficient obtained with the more detailed controls suggests that distressed firms disproportionately post positions in specific labor markets where postings tend to receive more applications. ${ }^{23}$

The magnitude of this decline in applications is sizeable when compared to the effect of other sources of job security such as union membership. Holzer, Katz, and Krueger (1991; Table III, column 3) estimate that a shift from full to no union coverage at a firm is associated with $0.12 \log$ points fewer applications. A 1,000 basis point increase in the CDS price thus has about twice the effect of changing from full to no unionization.

\subsection{Alternative specifications}

The reduction in applications is robust to various alternative specifications, including different measures of firms' financial condition, an alternative definition of job location, and other functional forms.

\footnotetext{
${ }^{23}$ Controlling for educational requirements, which are specified in some of the job postings, does not decrease the effect. As described in Section 5.2, 25,193 job postings require college and 11,802 explicitly require high school or less. Using this smaller sample and controlling for educational requirements in a specification otherwise similar to column 5.F, the coefficient on CDS price is -2.91 (s.e. $1.12 ; p<0.01$ ).
} 
We first examine two alternative measures of firms' financial condition: job seekers' perceptions and the stock price. Most job seekers do not observe firms' actual CDS prices. To consider more directly the relationship between job seekers' perceptions and behavior, we match the average financial scores from the survey, discussed in detail in Section 2, to job application data for the quarter in which the survey was conducted. Given the limited number of surveys, this sample is substantially smaller than in our baseline analysis of CDS prices. We estimate the impact of the financial score on the natural $\log$ of the number of applications, controlling for detailed job type-state-month interactions. The result, reported in column 6.A of Table 6, suggests that a one standard deviation lower financial score is associated with 33.7 log points fewer applications per job posting $(p<0.10)$.

We also consider firms' stock prices as an alternative high-frequency measure of firms' performance. Although both CDS and equity prices should reflect all available information about the firms' prospects and risk of default, these factors will manifest in the prices differently. ${ }^{24}$ CDS prices most directly reflect the probability of a credit event, in the case of our study, within the next five years for the firms' senior corporate bonds. A credit event is undoubtedly bad for potential employees, but poor corporate performance can lead to layoffs and impose other costs on workers even when the firm does not default on its debt. Such nondefaulting underperformance may more likely be reflected in firms' equity market value, although equity values reflect many other factors as well. ${ }^{25}$

Naturally, we expect the relationship between CDS and stock prices to be negative-

\footnotetext{
${ }^{24}$ Analyses of the relationship between the stock and CDS markets include Longstaff et al. (2003), Fung et al. (2008), Forte and Pena (2009), and Norden and Weber (2009).

${ }^{25}$ Strong corporate performance may also attract job seekers to a firm. Indeed, Davis, Faberman, and Haltiwanger (2013) find that growing firms fill vacancies more quickly. Whereas CDS prices mostly reflect the probability and severity of credit events, firms' equity prices also reflect corporate performance far from default.
} 
increases in a firm's default risk should be reflected in higher CDS prices and lower stock prices. Thus, we expect the relationship between the stock price and the volume of applications to be positive. In column 6.B, we report an estimate for the impact of a change in firms' stock prices. Controlling for firm fixed effects and detailed job type-state-month interactions, the estimates suggest that a $10 \%$ decrease in the stock price is associated with a $2 \%$ decrease in the number of applications per job posting $(p<0.01)$.

A related question is whether the effect of firms' financial condition on applications is concentrated among firms close to default. To explore heterogeneity in the effect, we replace the CDS price with indicators for a CDS price between the $25^{\text {th }}$ and $50^{\text {th }}$ percentiles, $50^{\text {th }}$ and $75^{\text {th }}$ percentiles, $75^{\text {th }}$ and $95^{\text {th }}$ percentiles, and above the $95^{\text {th }}$ percentile. ${ }^{26}$ In column $6 . C$, we present results for a specification with firm and detailed job type-state-month fixed effects. The effect is largest for firms experiencing the highest levels of distress. On average, firms with CDS prices above the $95^{\text {th }}$ percentile receive approximately $50 \log$ points fewer applications than firms with CDS prices below the $25^{\text {th }}$ percentile. ${ }^{27}$

We also confirm that the main results are not sensitive to the geographic definition of job locations. After replacing the state-level controls with metropolitan statistical area (MSA) controls, we estimate the main effect from a regression that includes firm and detailed job typeMSA-month interactions. As reported in column 6.D, the coefficient on CDS price is nearly identical in magnitude to the coefficient in the final regression in Table 5.

Finally, we examine another functional form. In column 6.E, we model a linear

${ }^{26}$ These percentiles correspond to the distribution of firms' monthly average CDS prices, without weighting by the number of jobs posted. The $25^{\text {th }}, 50^{\text {th }}, 75^{\text {th }}$, and $95^{\text {th }}$ percentiles are $93,161,304$, and 751 basis points, respectively.

${ }^{27}$ The results are also robust to winsorizing the key variables. Winsorizing the number of applications at its $5 \%$ tails leaves the CDS price coefficient almost unchanged at -2.29 (s.e. $0.78 ; p<0.01$ ), and winsorizing the CDS price at its $5 \%$ tails yields an estimate of is -5.41 (s.e. $2.04 ; p<0.01$ ), which is even larger in magnitude than those reported in Table 5. 
relationship between CDS price and the volume of applications. We again find a negative and statistically significant relationship. A 1,000 basis point increase in the CDS price is associated with about five fewer applications per open position $(p<0.05)$ - a decrease of approximately $9 \%$, relative to the mean. ${ }^{28}$

\subsection{Economic versus financial distress}

Although it is impossible for our analysis to definitively distinguish the labor supply effects of financing decisions from those of economic performance, the interpretation of our main findings depends on the importance of these two potential sources of distress. Economic distress almost certainly plays a role. Even if a firm is all-equity financed, its profitability is likely to influence its desirability as an employer, because struggling firms may lay off workers or shut down after a negative shock, even without the additional pressure of debt service. Given this possibility, one might ask: When we observe firms with high CDS prices having difficulty attracting workers, might this be because of the firms' economic performance, irrespective of their capital structures?

Although we are limited by the scarcity of measures that perfectly disentangle firms' economic and financial distress, we can shed some light on this question by examining other measures of firms' financing. The fixed effects in our baseline specification control for the effects of aggregate economic shocks at the detailed job type-state-month level. However, if financial distress is important, then we would expect more financially constrained firms to be more sensitive to these industrywide shocks. We explore this possibility using three distinct measures of firms' financial constraints, all measured prior to the onset of the 2008 financial

\footnotetext{
${ }^{28}$ Given the high variability in the number of applications per position (see Table 4), we measure application counts in logs in the main specifications.
} 
crisis: firms' total leverage, debt maturity, and loan covenants. In the first six columns of Table 7, we report results from a collection of regressions, all of which include firm and detailed jobtype-state-month fixed effects, that provide suggestive evidence of a significant relationship between the volume of applications and firms' preexisting capital structures during periods of industrywide distress.

Firms' Total Leverage-To consider whether firms with more aggressive capital structures attract fewer applicants during periods of industrywide distress, we regress the log volume of applications on the interaction of firms' debt-to-total assets ratio in the first quarter of 2008 and the monthly median CDS price in the financial services industry. ${ }^{29}$ (The main effects of both variables are absorbed by the firm and detailed job-type-state-month fixed effects.) The results are reported in column 7.A of Table 7. The interaction coefficient estimate is negative and statistically significant $(p<0.05)$, and its magnitude suggests that, for every standard deviation increase in industry median CDS price (63.7 basis points), firms with a one standard deviation higher debt-to-assets ratio (0.305) attract 5.7 log points fewer applications for an open position (i.e., $-29.370 \times 0.00637 \times 0.305=-0.057)$.

In an alternative specification reported in column 7.B, we replace the ratio with an indictor for a debt-to-asset ratio above the $75^{\text {th }}$ percentile in the sample. The coefficient estimate is again negative and statistically significant $(p<0.05)$, and its magnitude suggests that for every standard deviation increase in industry median CDS price, firms with leverage ratios above the $75^{\text {th }}$ percentile attract $5.9 \log$ points fewer applications than firms with less debt (i.e., $-9.186 \mathrm{x}$ $0.00637=-0.059)$. Both results are consistent with the notion that firms with relatively high debt

${ }^{29}$ Median monthly CDS prices were calculated for the 78 firms in the financial services industry with total assets in excess of $\$ 25$ billion for which CDS prices are available; the values are depicted in Figure 2. 
struggle to attract applicants during periods of widespread industry distress.

Debt Maturity — Next, we examine variation in the maturity structure of firms' long-term debt portfolios. We analyze whether firms whose debt places a greater demand on current cash flows - those whose debt includes more near-term obligations - attract fewer applicants. During the 2008 financial crisis, firms with large amounts of debt maturing faced tight financing constraints because of the reduced supply of traditional sources of corporate funding, including commercial paper, bonds, bank loans, and equity issuance (Almeida et al. 2011). Similar to Almeida et al. (2011), we compare firms with larger fractions of their long-term debt maturing in 2008 or 2009 - i.e., firms that are more likely to require refinancing during the crisis years - to other firms.

Using Compustat data from year-end 2007, we record how much debt was due in 2008 and 2009, respectively, and then calculate the ratio of each to the firm's total debt. We match these ratios to jobs posted in 2008 and 2009, respectively, and refer to it as the firms' current debt. For 2009, we use two-year-ahead data from year-end 2007 instead of one-year-ahead data from year-end 2008 so that the ratio does not reflect endogenous changes after the crisis began. The information on debt maturity is available for thirty of the forty firms in our dataset of job postings.

We regress the log volume of applications on the ratio of current to total debt and its interaction with the monthly industry median CDS price. We subtract the sample mean (156 basis points) from the industry CDS price before interacting it with the current debt ratio, so the ratio's main effect coefficient corresponds to the effect under average industry conditions. The results are reported in column 7.C of Table 7. The coefficient on the interaction is negative and statistically significant $(p<0.01)$, and its magnitude suggests that, for every standard deviation 
increase in industry CDS price, firms with one standard deviation more current debt $(0.089)$ attract $4.3 \log$ points fewer applications for an open position (i.e., $-75.234 \times 0.00637 \times 0.089=$ $-0.043)$.

In an alternative specification reported in column 7.D, we include an indicator for whether the ratio is greater than 0.1 and its interaction with the monthly industry CDS price. The coefficient estimate on the interaction is again negative and statistically significant $(p<0.01)$. For every standard deviation increase in industry CDS price, firms with high amounts of their debt due in the near term attract $7.5 \log$ points fewer applications for an open position (i.e., $-11.779 \times 0.00637=-0.075$ ). Both results suggest that firms with less short-term financial flexibility attract fewer applications during industry downturns.

Loan Covenants - Covenants in a firm's debt contracts may also impose constraints on its business. Thus, we examine whether firms subject to more debt covenants attract fewer applications to open positions. Using a 2012 extract of Loan Pricing Corporation's DealScan database, we identify completed loans that were active on January 1, 2008, for firms in our dataset of job postings. Thirty-one of the forty firms have at least one such loan package in DealScan. Some of these loans include covenants that give creditors the right to accelerate or terminate the loan if the firm violates a specified threshold in either leverage or interest coverage.

We regress the log volume of applications on the interaction of the dollar fraction of loans that include a covenant and the monthly industry median CDS price. ${ }^{30}$ (The main effects of both variables are absorbed by the firm and detailed job-type-state-month fixed effects.) The results are reported in column 7.E of Table 7. The interaction coefficient estimate is negative and statistically significant $(p<0.05)$, and its magnitude suggests that, for every standard deviation

\footnotetext{
${ }^{30}$ We linked the DealScan and Compustat firm identifiers using the crosswalk file developed by Chava
} and Roberts (2008). 
increase in industry CDS price, firms for which an additional standard deviation of their debt includes covenants (0.080) attract 1.5 log point fewer applications for an open position (i.e., $-29.146 \times 0.00637 \times 0.080=-0.015)$.

In an alternative specification reported in column 7.F, we replace the fraction with an indicator for firms for which more than $20 \%$ of their loans are subject to a covenant. The coefficient estimate is again negative and statistically significant $(p<0.05)$. The magnitude of the estimate suggests that, for every standard deviation increase in industry CDS price, firms for which at least $20 \%$ of loans are subject to covenants attract 9.0 log point fewer applications for an open position (i.e., $-14.061 \times 0.00637=-0.090$ ). Both results suggest that firms that are more constrained by loan covenants attract fewer applications to open positions during industry downturns.

Together, these results suggest that the characteristics of a firm's capital structureincluding its leverage, debt maturity, and loan covenants—can affect the firm's ability to attract workers during a downturn. However, these relations might not have a causal interpretation. One natural concern is that, although these capital structure characteristics are pre-determined (i.e., they were all chosen before the crisis set in), they could be correlated with the firm's asset structure, which in turn could be correlated with the firms' sensitivity to economic distress. The detailed job-type-state-month fixed effects in our baseline specification account for many aspects of firms' economic conditions, including both industry trends and location-specific geographic variation. Nevertheless, some uncontrolled firm-specific economic factors might remain.

To address this possibility, we add contemporaneous and lagged quarterly return on assets (ROA) to our baseline model of job applications and assess whether applications remain correlated with firms' CDS prices even after controlling for these firm-specific measures of 
profitability. Because ROA data is available only quarterly, we conduct the analysis in two ways. In column 7.G, we report estimates using the same firm-specific monthly average CDS price examined in our baseline analysis; and in column 7.H, we report estimates using the firms' average CDS price over the quarter to match the frequency of our measure of return on assets. ${ }^{31}$ In both specifications, the coefficient on CDS price is negative and statistically significant-a 1,000 basis point increase in the CDS price is associated with a 33 to $46 \log$ point decline in applications $(p<0.05)$. In contrast, the coefficients on current and lagged return on assets are not statistically significant at conventional levels, suggesting that operating performance alone-at least as measured by ROA—does not explain job applications' sensitivity to firms' distress.

\section{Why do applications decrease?}

Sections 2 and 3 present evidence that job seekers both perceive and respond to changes in firms' financial condition. In this section, we ask "why?" We consider competing explanations for the relationship and conclude that a reduction in labor supply to distressed firms plays an important role.

\subsection{Labor demand}

Although our main analysis has focused on job seekers' decisions, we consider the possibility that changes in firms' labor demand underlie the applicants' behavior. We evaluate two potential demand-side explanations: (1) firms' hiring needs become more specialized during

\footnotetext{
${ }^{31}$ The sample size reported in Table 7, columns 7.G and 7.H, is considerably smaller than in the baseline specification because ROA data were not available for eight firms and only partially available for fourteen others. When we estimate a specification similar to column 5 .F of Table 5 on this smaller sample, the coefficient on CDS price is -2.71 (s.e. $1.36 ; p<0.05$ ). As we would expect, CDS prices and ROA are negatively correlated, and regressing the log of the number of applications on ROA without controlling for CDS price yields a positive coefficient on ROA.
} 
periods of distress and (2) distress constrains firms' ability to compensate workers.

Firms' human capital needs may change when they are distressed. For example, a distressed commercial bank may be more focused on servicing existing loans than on originating new loans.; as a result, hiring may shift from loan officers to collection specialists. To the extent that distressed firms recruit for specialized positions, the decline in observed applications might be attributable to a smaller pool of potential applicants rather than to workers having reduced interest in these firms. If distress shifts hiring across job classifications-for example, from marketing to accounting - then these effects would be captured by the detailed job type controls in Section 3. However, these controls would not account for hiring changes within a given job classification toward positions with smaller baseline applicant pools.

To evaluate this possibility, we analyze changes in the volume of applications for particular jobs. Every job posting in the dataset includes a specific job title-for example, Agricultural Loan Officer. Across all firms, the data include nearly 33,800 unique job titles. To confirm the homogeneity of jobs posted with the same job title, we examine variation in their salaries. Salary information was included in 6,391 job postings in the sample; we do not observe nonmonetary compensation, such as health insurance or other benefits. ${ }^{32}$ Whereas the coefficient of variation of posted salaries across all jobs is 1.20 , the average coefficient of variation within a job title at a given firm in a given state is only 0.02 . This suggests that job characteristics are similar across positions with the same job title.

In the analysis presented in column 8.A of Table 8, we augment our baseline

\footnotetext{
${ }^{32}$ The salary information is coded into categories of $\$ 5,000$ increments for salaries up to $\$ 100,000$ and $\$ 25,000$ increments for salaries between $\$ 100,000$ and $\$ 500,000$. In our analysis, we use the midpoint of each category and recode salaries above $\$ 500,000$ to $\$ 650,000$. The results discussed here and those reported in Table 8 are robust to using alternative recoding values and to excluding job postings with salaries over $\$ 500,000$. The median annual base salary is $\$ 52,500$, with an interquartile range of $\$ 32,500$ to $\$ 97,500$.
} 
specification with fixed effects for each job title. The analyses reported in columns 8.B and 8.C include even more demanding controls, capturing fixed effects for each individual job title in each firm and for each job title within each firm in each state, respectively. In all of these specifications, the coefficient is negative and statistically significant-a 1,000 basis point increase in the CDS price is associated with a 9.6 to $11.3 \log$ point decrease in applications $(p<$ 0.05). Together, these estimates suggest that the main result—-that firms' distress is associated with a lower volume of applications - is not being driven exclusively by changes in the human capital needs of distressed organizations.

Even if firms' human capital needs are not changing, distress may constrain their ability to hire. If applicants dislike working for distressed firms, then firms may need to offer higher salaries to attract the same number of applications. But distressed firms may not have the resources to increase (or even maintain) their salary offers to new employees. In this case, we might observe fewer applications because of lower salaries, but not because of increased layoff risk or other labor supply considerations.

To investigate this potential demand-side explanation, we examine how salaries change when firms experience distress. ${ }^{33}$ Columns 8.D through 8.F of Table 8 present results from regressions analyzing the natural $\log$ of the posted salary as the dependent variable. To focus on salary changes for specific jobs, we again include job title, firm, and state fixed effects and their interactions. The estimates suggest that, if anything, firms offer higher salaries to attract applicants during periods of distress. A 1,000 basis point increase in the CDS price is associated with a 16 to $18 \log$ point increase in salary. These estimates are somewhat less precise than for

\footnotetext{
${ }^{33}$ We find no evidence that a firm's distress affects its propensity to post salary information. In regressions of an indicator for salary information availability with controls similar to those in Table 8 , the coefficients on CDS price are negative and not statistically significant. The estimates range from -0.9 (s.e. 1.2) to -1.6 (s.e. 2.4) percentage points for a 1,000 basis point increase in the CDS price.
} 
application volumes, which is expected given the smaller sample size. The estimated increase in salaries is consistent with the literature on compensating differentials for unemployment risk (see Rosen 1986 for a survey) and squares well with Graham et al.'s (2013) estimates of workers' wage loss following a corporate bankruptcy. ${ }^{34}$

Overall, we find no evidence that changes in labor demand can fully explain our results.

\subsection{Labor supply}

Another possibility is that corporate distress affects labor supply—when offered similar positions and the same wage, workers prefer to work for a firm that is in a better financial condition. Distress reduces job security (Hotchkiss 1995; Agrawal and Matsa 2013), which imposes both psychological (Sverke and Hellgren 2002) and economic costs (Maksimovic and Titman 1991; Graham et al. 2013), even for workers who remain with the firm. The costs of unemployment are even more substantial (Katz and Meyer 1990; Gibbons and Katz 1991; Gruber 1997). Given all of these costs, job seekers might avoid distressed firms, making it difficult for these firms to recruit new workers.

\subsubsection{Role of unemployment insurance}

We explore the role of labor supply in two ways. First, we exploit state-level variation in the unemployment insurance system. Although the basic structure of UI is common throughout the United States, there are substantial differences in the generosity of benefits across states. In every state, eligible claimants receive weekly benefit payments for a set number of weeks,

\footnotetext{
${ }^{34}$ Using 138 firms' public bankruptcy filings, Graham et al. (2013) estimate that, over the five years following a bankruptcy, an average worker suffers a wage loss of $132 \%$ of their pre-bankruptcy wage. Given that the increase in the five-year cumulative default rate associated with a 1,000 basis points change is 16.6 percentage points (see footnote 19), one might conclude that an employee would require a $22 \%$ wage premium as a compensating wage differential.
} 
determined by their employment histories. Following Agrawal and Matsa (2013) and Hsu, Matsa, and Melzer (2014), we measure the generosity of states' UI systems using the product of the maximum benefit amount and the maximum duration. ${ }^{35}$ We use states' maximum UI benefits in January 2009, which averaged $\$ 11,500$ (standard deviation $\$ 3,600$ ).

More generous UI benefits reduce workers' costs of unemployment. To the extent that job seekers' behavior is influenced by concerns about job security, more generous UI benefits could mitigate these concerns and make workers less sensitive to firms' distress. Empirically, this would reduce the sensitivity of the volume of applications to CDS prices. ${ }^{36}$ In the analyses reported in Table 9, we interact CDS prices with the log maximum UI benefit in the state in which the job is located. Although the coefficient is not reported in the table, we also control for the uninteracted UI variable in specifications in which it is not absorbed by the fixed effects. To ease interpretation of the CDS main effect, the sample mean is removed from the log maximum UI benefits prior to the interaction.

We find that workers are more willing to apply to positions at distressed firms in states in which unemployment costs are lessened by a stronger social safety net during unemployment. Column 9.A of Table 9 presents results from the baseline specification with firm and month fixed effects. Whereas a 1,000 basis point increase in the CDS price is associated with a $19 \log$ point decline in the number of applications in a state with average maximum UI benefits, this sensitivity is $7 \log$ points lower for states with $25 \%$ higher UI benefits $(p<0.05)$. This

\footnotetext{
${ }^{35}$ Although ideally we would focus on individual job-level variation in the ratio of the UI benefit to wages, the limited availability of wage data precludes us from adopting this approach. Instead, we exploit state-level differences in UI systems using maximum benefit levels - the primary source of cross-state variation in UI generosity (Moffitt and Nicholson 1982). As an additional test, we exploit variation based on the positions' educational requirements as a proxy for workers' income and liquid savings (see footnote 37).

${ }^{36}$ In theory, more generous UI could also make unemployed job seekers collecting UI choosier, which might amplify applications' sensitivity to CDS prices. We estimate the net effect.
} 
relationship is robust to the various specifications. As we control for more detailed labor market variation, the point estimates increase in magnitude. Results from an analysis with firm and detailed job type-state-month fixed effects are presented in column 9.F. Here, a $25 \%$ increase in maximum UI benefits cuts the sensitivity of applications to CDS prices nearly in half, from 22 to $12 \log$ points $(p<0.01){ }^{37}$

We find that UI also moderates the compensating salary differentials offered by distressed firms. Column 9.G presents regression results analyzing the natural log of the posted salary as the dependent variable, augmented with the interaction of CDS prices with the $\log$ maximum UI benefit in the state in which the job is located. The positive coefficient on CDS price indicates that posted salaries are higher at distressed firms in states with average maximum UI benefits $(p<0.05)$, and the negative CDS-UI interaction coefficient suggests that this compensation premium is lower for workers who qualify for greater UI benefits $(\mathrm{p}<0.05) .^{38}$

The importance of UI generosity further reinforces the relevance of our results for firms' capital structure decisions. The effect of UI generosity on the sensitivity of applications and salaries to corporate distress suggests that concerns specifically about job security underlie much of the reduction in labor supply to distressed firms, and existing studies have shown that financial distress often leads companies to downsize their workforce. Using a regression

\footnotetext{
${ }^{37}$ As a further test, we split the sample based on jobs' educational requirements. Because college graduates typically have greater liquid savings and because UI benefits typically cover a smaller fraction of their lost income, college graduates are likely to be less sensitive to marginal differences in UI generosity (Chetty 2008). Consistent with this prediction, the interaction between CDS price and UI benefits is stronger for jobs with lower educational requirements. In an analysis with firm and detailed job type-state-month fixed effects, a $25 \%$ increase in the maximum UI benefit lowers the sensitivity of the number of applications to changes in CDS prices by $25 \mathrm{log}$ points (s.e. 10) for jobs requiring only high school education and $7 \log$ points (s.e. 8) for jobs requiring a college degree.

${ }^{38}$ In specifications with job title controls, the coefficient estimates on CDS price are similar in magnitude and statistical significance to those presented in Table 8 (columns D-F), and the interaction coefficients are negative but not statistically significant at conventional levels. Comparing specifications with and without job title controls, the difference in the coefficient estimates suggests that firms post higher wage job titles during periods of distress.
} 
discontinuity design to control for firms' economic distress, Falato and Liang (2012) find that covenant violations cause firms to cut their workforces by about $10 \%$. When comparing firms that default on a bond to nondefaulting firms in the same industry and with similar economic performances, Agrawal and Matsa (2013) find large reductions in employment among the defaulting firms and no change among the others. They conclude that the financial distress associated with bond defaults decreases employment by $27 \%$ in the two years surrounding a default. Moreover, Hotchkiss (1995) finds that employment decreases by about 50\% around a bankruptcy filing. ${ }^{39}$ Given that financial distress reduces job security and that limited job security reduces workers' labor supply, firms looking to attract and retain employees have reason to limit their borrowing.

\subsubsection{Role of worker relocation costs}

To further explore the role of labor supply, we examine whether large upfront costs make job seekers reluctant to apply to distressed firms. Specifically, we study the role of relocation costs. When a prospective employer's financial future is uncertain, the desirability of open positions may be particularly weak for workers who have to relocate for the job; strong local familial and social ties can act as geography-specific investments that reduce worker mobility (Alesina et al. 2013). Non-local job seekers may be reluctant to make the substantial upfront investment of relocating for a job whose long-run prospects are uncertain.

To examine this mechanism empirically, we limit our sample to job postings for which we observe at least $80 \%$ of the applicants' states of residence. For these jobs, $21.5 \%$ of applicants live outside of the state in which the job is located; many of these applicants would likely have to relocate if they took the position. In Table 10, we analyze the percentage of

\footnotetext{
${ }^{39}$ Hotchkiss does not report the contemporaneous change in employment among other firms.
} 
applications from out of state. The regressions are weighted by the number of applications for which location data are available to account for differences in the precision of the out-of-state measure.

We find that firms' distress decreases the proportion of applications from out of state. The coefficient on CDS price is negative and sizable. When controlling only for firm and month fixed effects, the coefficient estimate is large but imprecise (column 10.A). Adding more detailed job market controls reduces the estimate's standard error substantially. With controls for firm and detailed job type-state-month, the estimate is significant at the $1 \%$ level. A 1,000 basis point increase in the CDS price is associated with a 1.7 percentage point decrease in the proportion of out-of-state applications (column 9.F). Relative to the sample mean of $21.5 \%$, this effect represents a 7\% decrease in the proportion of out-of-state applications.

The reduction in out-of-state applications has strategic implications for distressed firms. Out-of-state applicants are particularly valuable to firms when local workers lack the skills required for open positions. Distress appears to constrain firms' ability to attract workers from the national labor market, potentially preventing them from hiring workers with the appropriate skills. This challenge in accumulating human capital may contribute to distressed firms' struggles to regain financial stability.

Together, the analysis of unemployment costs and relocation costs suggests that workers' labor supply indeed responds to firms' financial condition. We conclude that the decrease in job applications to distressed firms at least partially reflects worker preferences, not strictly changes in firms' labor demand. 


\section{Potential implications for firms' human capital}

The negative effect of corporate distress on labor supply has potential implications for distressed firms' accumulation and retention of human capital. Although a full examination of these issues is beyond the scope of our data, further analysis provides some indication of how the quality of the applicant pool changes with firms' distress, which positions are most affected, and whether current employees' labor supply also decreases.

\subsection{Quality of the applicant pool}

A company's distress may affect not only the volume but also the quality of applicants to open positions in the firm. In deciding whether to apply, potential job applicants balance the expected value of a new position against their alternatives in the broader labor market. When a potential employer becomes distressed, the increased risk of unemployment lowers the value of working for the firm. Given the greater unemployment risk, workers who face greater unemployment costs, are more risk averse, or have better outside options may be especially reluctant to apply. These changes could affect the quality of the applicant pool if, for example, workers with attractive outside options are also the most productive.

To explore whether firms' distress affects the quality of job applicants to open positions, we match applicants' locations to ZIP code demographics from the 2000 United States Census. Unfortunately, we do not observe detailed characteristics of the specific applicants in our data. The job search platform does not archive the individual PDF resumes uploaded with each job application. Although the platform separately collects resume information from some users, they were unable to match those data with many applications for the purposes of this research. Nevertheless, by examining applicants' ZIP codes, we gain some insight into their backgrounds. 
Table 11 reports results of regressions using four measures of applicant quality. Columns 11.A and 11.B examine the natural logs of the mean and median of average earnings (among people sixteen years and older with earnings) in applicants' ZIP codes; columns 11.C and 11.D examine the mean and median of the percentage of the population in applicants' ZIP codes with a four-year college degree. As in the analysis reported in Table 10, we limit our sample to job postings for which we observe at least $80 \%$ of the applicants' location. All regressions include firm and detailed job type-state-month fixed effects and are weighted by the number of applications for which location data are available.

The results suggest that distressed firms struggle to attract high-quality applicants to open positions. An increase in the CDS price is associated with a statistically significant decline in applicants' ZIP codes' earnings - a rough measure of applicants' past earnings and ability. A 1,000 basis point increase in the CDS price is associated with a 2 log point decline in ZIP code earnings ( $p<0.10$ and $p<0.05$; columns 11.A and 11.B). An increase in the CDS price is also associated with a decrease in the education of the applicant pool. A 1,000 basis point increase in the CDS price is associated with a 0.7 to 1.1 percentage point reduction in applicants' ZIP codes' college completion rate - a $3 \%$ to $4 \%$ decrease relative to the sample mean of $27.6 \%(p<0.10$ and $p<0.01$; columns 11.C and 11.D).

These estimates, combined with results from the existing labor literature, provide some insight into how much the decline in human capital affects firms' value during periods of distress. Because our data provider does not observe who is ultimately hired for posted positions, we must assume that the quality of the person hired is affected similarly to the applicant pool. ${ }^{40}$ Although this and other complications make it impossible to quantify the effect exactly, the

\footnotetext{
${ }^{40}$ Although it is impossible with our data to confirm changes in the quality of the person actually hired, our results on posted wages suggest that, regardless of who is hired, a distressed firm faces a substantially higher payroll expense, which is an additional cost of distress.
} 
following calculation provides a context for understanding the economic implications of our results.

Using a cross-section of employee microdata, Abowd et al. (2005) construct a measure of human capital and show that a one standard deviation increase in a firm's proportion of aboveaverage workers is associated with a $14 \log$ point increase in market value. Assuming that this relationship is causal and that any change in the quality of the existing workforce is commensurate with the decline in applicant quality, we can use the estimates from our analysis in Table 11 to estimate the value impact of the decline in the quality of labor supplied to a firm in distress. ${ }^{41}$ Averaging over the columns in Table 11, a 1,000 basis point increase in the CDS price is associated with a 0.14 standard deviation decline in applicant quality and an average standard error of 0.07 standard deviations. Applying the estimate from Abowd et al. (2005) and allowing for a two-standard deviation (68\%) confidence interval, we find that a 1,000 basis point increase in the CDS price is associated with a 1 to $3 \log$ point decline in firm value. ${ }^{42}$ In our sample, a 1,000 basis point increase in the CDS price is associated with a total decrease in firm value of 8 $\log$ points. ${ }^{43}$ Thus, the decrease in worker quality accounts for up to one-third of the total decline

\footnotetext{
${ }^{41}$ The assumption that the quality of the existing workforce declines with the quality of the new recruits is strong. On one hand, the volume of posted positions in our sample is only approximately $7 \%$ of an average firm's workforce (as reported in Compustat); therefore, if new and existing workers' activities in the firm are completely independent, the impact of the change of CDS price on firm value could be relatively small. On the other hand, many jobs with high educational requirements (such as Wall Street traders) are not posted on the online platform that we study (and labor supply to these positions may be even more sensitive, as results reported in Table 12 suggest). Furthermore, if workers engage in team production, there could also be substantial spillovers between the new recruits and existing employees in terms of productivity, leading to larger than proportional changes in firm value.

${ }^{42} \mathrm{We}$ examine mean and median of measures of applicant quality to reflect the fact that firms are not always able to hire the best applicant in the pool (e.g., Lang 1991). Although their precision varies, point estimates from regressions using other percentiles in the distribution imply declines in firm value that also fall approximately within this range.

${ }^{43}$ The estimate of $8 \mathrm{log}$ points is obtained from an analysis of quarterly Compustat data from 2007 through 2011 in which we regress the market value of firms' assets (defined as the book value of assets plus the difference between the market and book values of common equity) on CDS prices and firm fixed effects.
} 
in firm value associated with distress. This quality cost is in addition to the higher payroll expense implied by our estimates of distressed firms' compensating wage differential (see Section 4.1). Although speculative and imprecise, the magnitude of these estimated effects suggest that the employment-related costs of distress may be substantial. ${ }^{44}$

Section 3 shows that the volume of applications decreases in distress, and the results here suggest that the declining quality of the shrinking pool of applicants may have significant consequences for the firm. Taken together, these findings highlight the potentially reinforcing nature of a firm's distress - poor performance may be exacerbated by the firm's inability to attract high-quality workers who can assist in its recovery.

\subsection{Heterogeneity in human capital acquisition}

Distress may not affect hiring for all positions equally — the volume of applications for some positions may be more sensitive to distress than others. Workers who suffer the most from being laid off are likely especially sensitive to job insecurity. These workers include, for example, people whose specific skills make it difficult to find a good employment match, jobs that require firm-specific investments, and positions with steep wage-tenure profiles. Workers may also differ in their awareness of employers' financial condition.

Irrespective of the underlying mechanisms, describing cross-worker heterogeneity in responsiveness to corporate distress can shed light on which types of human capital are most sensitive to firms' financial position. To this end, we divide job postings by educational

\footnotetext{
${ }^{44}$ Even though this exercise involves a number of assumptions, the results turn out to align quantitatively with other estimates in the literature. A drop from a BBB to B rating is associated with a risk-adjusted cost of financial distress of 5\% in Almeida and Philippon (2007, Table VI) and a 1\% wage premium in Agrawal and Matsa (2013, Table 9). Summing those effects and the effect of lower quality workers estimated here $(2 \%)$ yields a total change in firm value of $8 \%$, which is similar in magnitude to our estimate of the total change in firm value (see footnote 43 ).
} 
requirements. Data on educational requirements are available for approximately $40 \%$ of the job postings. Of these, approximately $65 \%$ require a four-year college degree and $35 \%$ require only high school education.

The results are reported in Table 12 for three different specifications for firm, month, location, and job-type controls. For lower-education jobs, the estimated coefficients for CDS price vary substantially across the specifications and are not statistically significant at conventional levels (columns 12.A through 12.C). In contrast, the coefficient estimates on the CDS price are negative, sizable and consistent in magnitude, and statistically significant for jobs requiring a college education. A 1,000 basis point increase in the CDS price is associated with a 21 to $28 \log$ point decline in applications to jobs requiring a college degree $(p<0.10$ and $p<$ 0.05; columns 12.D through 12.F).

Comparing coefficient estimates across the two samples yields mixed results in different specifications. On one hand, analysis with firm, state-month, and detailed job type controls finds the effect of CDS price to be much larger for positions requiring college and the difference to be highly statistically significant ( $p<0.01$; columns $12 . \mathrm{B}$ and 12.E). On the other hand, analysis with the most saturated controls finds similar point estimates across the samples; there are large differences in precision, which is unsurprising given the difference in sample sizes (columns 12.D and 12.F). The differences in the estimates from the third specification are in between these extremes. Overall, however, the relative sizes of the coefficients in Table 12 suggest that the effect identified in Table 5 may largely reflect the sensitivity of applicants pursuing jobs with high educational requirements.

We propose two potential explanations for why skilled workers may be more sensitive to firms' distress — highly educated workers may be more knowledgeable about firms' financial 
condition and/or they may expect to suffer greater costs in the case of corporate distress. Highly educated workers likely bear greater expected distress costs, in part, because of their steeper wage-tenure profiles (e.g., Connolly and Gottchalk 2006). Expected total job tenure also increases with education, further magnifying potential losses due to firms' distress (Topel 1991; Topel and Ward 1992).

Multiple underlying models can explain the differential wage-tenure profiles. First, the firms could be using deferred compensation, whereby firms pay senior employees more than their marginal product and junior employees less in order to motivate workers early in their tenure (Lazear 1979). Such schemes rely on the continued solvency of the firm. If jobs requiring more education are also ones with established internal "career paths" and steep seniority-wage profiles, then workers qualified for those positions may be reluctant to apply when the firm's future is uncertain. Second, the differential wage-tenure profiles may be supported by specialized investments in human capital. Applicants seeking jobs that require greater investment in firmspecific human capital face higher unemployment costs. Uncertainty over the future condition of the firm makes such investment unattractive to new employees. Consequently, investment in human capital declines when workers face possible separation from the firm (Jovanovic 1979).

More educated job seekers may also be more informed about, and therefore more sensitive to, firms' financial condition. In our empirical context-the financial services industry - the positions requiring higher education include jobs relating directly to corporate finance, capital markets, and investing. As these job listings target applicants with an interest and aptitude in finance and related fields, these individuals may be more aware of firms' financial condition. ${ }^{45}$ In contrast, the positions that do not require advanced education may attract

\footnotetext{
${ }^{45}$ Although finance knowledge may play a role, applicants' sensitivity to firms' distress is not limited finance-related jobs. Using the postings' job-type classifications, we can analyze the importance of firms'
} 
applicants with more limited knowledge or interest in current events in business.

Although we cannot tease apart these potential mechanisms, our empirical findings suggest that jobs with more demanding educational requirements may attract even fewer applications when firms are distressed. Distressed firms thus face particularly acute challenges in recruiting for skilled positions, likely impeding these firms' accumulation of human capital.

\subsection{Human capital retention}

To shed light on distressed firms' ability to retain talent, in a final analysis, we examine firms' total number of employees and job postings. Over the study period, distressed firms reduced their total workforces and reduced them by more than other firms. The first two columns of Table 13 report results from an analysis of employment data from Compustat, which are available only on an annual basis. First, we regress the percentage change in a firm's number of employees from December 2007 to December 2009 on the firm's maximum CDS price in that period. As reported in column 13.A, the coefficient on the CDS price is negative and statistically significant - a 1,000 basis point increase in the maximum CDS price is associated with an $11 \%$ decline in the number of workers in the firm over the two years $(p<0.01)$. In the analysis reported in column 13.B, we examine the impact of distress on an indicator for negative net labor force growth over the two-year period. We find that a 1,000 basis point increase in a firm's maximum CDS price is associated with a nearly 20 percentage point increase in the probability that the firm's labor force shrinks $(p<0.01)$.

The aggregate reductions in the labor force of distressed firms might reflect decreases in

distress for non-finance positions. After excluding finance-related positions, the coefficient on CDS price is -1.75 (s.e. $0.50 ; p<0.01$ ) in a specification that controls for firm and detailed job type-state-year fixed effects (similar to the specification reported in column 5.F of Table 5). The magnitude of this estimate is smaller than for the full sample but still sizeable and statistically significant. 
labor demand. After all, distressed firms are often forced to lay off employees to cut costs. But decreases in the supply of labor at distressed firms might play a role in the aggregate reductions as well, if current employees leave for more secure jobs elsewhere and it is difficult to attract qualified applicants to replace them. To shed light on this possibility, we examine the quantity of job postings in this period. If the reductions in employment are completely explained by decreases in labor demand, then we should observe a concomitant relative decline in the volume of job postings. If the relative number of positions posted does not decrease, then this suggests that distressed firms suffer greater attrition by current employees.

Table 13 also presents results from regressions examining the number of jobs posted. Looking over the entire sample period, the total number of jobs posted is positively related to a firm's maximum CDS price-a 1,000 basis point increase in the maximum CDS price is associated with about six additional job postings over the 21-month period $(p<0.10$; column 13.C). Because we observe the precise timing of job postings, further analysis is also possible. Using firm-month panel data, we regress an indicator for whether any positions are posted (column 13.D) or the log of the number of positions (conditional on any posting; column 13.E) on firms' contemporaneous CDS prices and firm and month fixed effects. The month fixed effects control for aggregate movements in job postings, including the precipitous drop after October 2008 depicted in Figure 4. The coefficient estimate is positive for both dependent variables and is significantly different from zero for the number of positions posted - a 1,000 basis point increase in the CDS price is associated with a $20 \log$ point increase in the number of postings ( $p<0.10$; column 13.E). None of these three estimates show any indication of a relative decrease in recruiting, despite the firms' contemporaneous decrease in total employment. ${ }^{46}$

\footnotetext{
${ }^{46}$ We also find little evidence that distressed firms, anticipating a decline in applications per job posting, were able to attract a similar number of applicants by advertising the job multiple times. Unfortunately,
} 
Put together, distressed firms' overall decline in employment and lack of decrease in recruiting suggest that they experience greater employee turnover. In periods of weak corporate financials, current workers facing uncertain job security may search for more stable work elsewhere. Our previous analyses found that new job seekers were less likely to be attracted to distressed firms; the results presented in Table 13 suggest that a similar attitude may prevail among current employees - in their case, a reluctance to remain aboard a sinking ship. Distressed firms appear to actively recruit to offset the loss of current employees, but these firms face a human resource challenge: as our evidence suggests, finding workers to fill vacancies can be particularly difficult just when the firm needs them the most.

\section{Conclusion}

Using several unique datasets from a large online job search platform, we find that the volume and quality of applicants attracted to open job postings decline when firms become distressed, with potentially large consequences for firms' value. Evidence suggests that shifts in labor demand cannot fully explain the decline in applications- the results hold for same-job analysis, and advertised salaries, if anything, increase. Instead, the decline appears to be at least partly driven by changes in labor supply. Indeed, we confirm that job seekers accurately perceive deterioration in individual firms' financial condition and that applications decrease more among workers facing greater upfront costs because they must relocate from out of the state.

Job seekers seem to be avoiding jobs at distressed firms, at least in part, to reduce their

because we cannot identify individuals applying to each posting, we can only observe the number of applications and not the number of applicants. As a result, we overcount applicants applying to multiple postings when we aggregate across postings and understate the negative effect of CDS price on the total number of unique applicants. Nevertheless, in regressions with the natural log of the count of applications aggregated to either the firm-state-month-detailed job type level or the firm-state-month-job title level as the dependent variable, the estimated coefficients on the CDS price are consistently negative, although not always statistically significant. 
exposure to unemployment risk. We find that applications from workers with greater protection provided by state unemployment insurance are less sensitive to changes in the firms' financial condition. Although UI is well known to undermine unemployed individuals' incentives for job search (Nicholson and Needels 2006), our results suggest that UI can also encourage employment by providing a safety net. We also find that distressed firms find it particularly challenging to recruit for positions typically filled by workers for whom job loss would be especially costly, such as jobs with demanding educational requirements.

Although it is impossible to know for sure, our analysis suggests that job seekers respond to firms' financial distress in addition to firms' economic performance. During the Great Recession, the volume of applications decreased most among sample firms with more constraining capital structures-firms with greater leverage and whose debt had shorter maturity and more covenants. Furthermore, applications were highly correlated with the firms' CDS prices, a measure of their default risk, even after controlling for firms' operating performance. Finally, we find that the decline in applications was related, at least in part, to concerns about job security, which is known to decrease when firms are in financial distress (Falato and Liang 2012; Agrawal and Matsa 2013).

These results suggest a channel through which distress reinforces distress: a struggling firm may be unable to retain and attract workers who could contribute to recovery. These challenges are likely to be magnified in a recession when unemployment costs are all the more salient to workers. We find that distress reduces firms' access to the national labor market, reduces the quality of the applicant pool, increases the salaries firms offer, and makes it particularly challenging to recruit for jobs with demanding educational requirements.

More broadly, our results imply that labor market frictions are an important consideration 
for corporate decisions related to risk taking-decisions including financial, operations, innovation, and growth strategies. The labor-related costs that we study provide firms with a strong incentive to avoid distress. Firms can abate these costs in various ways. Most directly, firm can reduce leverage and choose more conservative financial policies (Titman 1984; Berk, Stanton, and Zechner 2010; Agrawal and Matsa 2013). Firms can also reduce the probability of distress by reducing operating leverage (Lev 1974) or by taking less risky projects (Hennessy and Whited 2005), or can mitigate workers' costs of distress by redesigning job tasks to require fewer firm-specific skills (Jaggia and Thakor 1994). Exploring the impact of labor market frictions on such corporate strategies is an important area for future research.

\section{References}

Abowd, J., and O. Ashenfelter. 1981. "Anticipated Unemployment, Temporary Layoffs, and Compensating Wage Differentials." In: Rosen, S. (Ed.), Studies in Labor Markets University of Chicago Press, Chicago.

Abowd, J. M., J. Haltiwanger, R. Jarmin, J. Lane, P. Lengermann, K. McCue, and K. Sandusky. 2005. "The relation among human capital, productivity, and market value: Building up from micro evidence." In: C. Corrado, J. Haltiwanter, and D. Sichel, editors: Measuring capital in the new economy. University of Chicago Press: 153-204.

Agrawal, A. K., and D. A. Matsa. 2013. "Labor Unemployment Risk and Corporate Financing Decisions." Journal of Financial Economics, 108: 449-470.

Alesina, A.F., Y. Algan, P. Cahuc, and P. Giuliano. 2013. "Family Values and the Regulation of Labor.” NBER Working Paper 15747.

Almeida, H., M. Campello, B. Laranjeira, and S. Weisbenner. 2011. "Corporate Debt Maturity and the Real Effects of the 2007 Credit Crisis." Critical Finance Review, 1: 3-58.

Altman, E., and S. Ramayanam. 2007. "Defaults and Returns in the High-Yield Bond Market: 2006 in Review and Outlook." NYU Salomon Center Special Report.

Averett, S., H. Bodenhorn, and J. Staisiunas. 2005. "Unemployment Risk And Compensating Differentials In New Jersey Manufacturing.” Economic Inquiry, 43: 734-749.

Benmelech, E., and N. Bergman. 2011. "Bankruptcy and the Collateral Channel." Journal of Finance, 66: 337-78. 
Benmelech, E., N. Bergman, and R. Enriquez. 2012. "Negotiating with Labor under Financial Distress." Review of Corporate Finance Studies, 1: 28-67.

Berk, J., R. Stanton, and J. Zechner. 2010. "Human Capital, Bankruptcy, and Capital Structure." Journal of Finance, 65: 891-926.

Borenstein, S., and N. L. Rose. 2003. "The Impact of Bankruptcy on Airline Service Levels." American Economic Review, 93: 415-419.

Card, D. 2011. "The Return of the Firm to Labor Economics." Presidential Address at the Annual Conference of the Society of Labor Economists, April 2011, Vancouver.

Chava, S., and M. R. Roberts. 2008. "How Does Financing Impact Investment? The Role of Debt Covenants," Journal of Finance, 63: 2085-2121.

Chen, J., M. Kacperczyk, and H. Ortiz-Molina. 2011. "Labor Unions, Operating Flexibility, and the Cost of Equity." Journal of Financial and Quantitative Analysis, 46: 25-58.

Chetty, R. 2008. "Moral Hazard vs. Liquidity and Optimal Unemployment Insurance.” Journal of Political Economy, 116: 173-234.

Chevalier, J. A. 1995a. "Capital Structure and Product-Market Competition: Empirical Evidence from the Supermarket Industry.” American Economic Review, 85: 415-35.

Chevalier, J. A. 1995b. "Do LBO Supermarkets Charge More? An Empirical Analysis of the Effects of LBOs on Supermarket Pricing.” Journal of Finance, 50: 1095-1112.

Chevalier, J. A., and D. S. Scharfstein. 1996. "Capital-Market Imperfections and Countercyclical Markups: Theory and Evidence.” American Economic Review, 86: 703-25.

Connolly, H., and P. T. Gottchalk. 2006. "Differences in Wage Growth by Education Level: Do Less-Educated Workers Gain Less from Work Experience?” IZA Discussion Paper No. 2331.

Daniels, K. N., and M. S. Jensen. 2005. "The effect of credit ratings on credit default swap spreads and credit spreads." The Journal of Fixed Income, 15: 16-33.

Davis, S. J., R.J. Faberman, and J.C. Haltiwanger. 2013. “The Establishment-Level Behavior of Vacancies and Hiring.” Quarterly Journal of Economics, 128: 581-622.

Davis, S. J., and T. von Wachter. 2011. "Recessions and the Costs of Job Loss." Brookings Papers on Economic Activity, Fall: 1-72.

Falato, A., and N. Liang. 2012. "Do Creditor Rights Increase Employment Risk? Evidence from Debt Covenants.” Working paper, Federal Reserve Board.

Fishback, P.V. 1998. “Unfettered' Labor Markets: Exit and Voice in American Labor Markets at the Turn of the Century." Journal of Economic Literature, 36: 722-765.

Forte, S., and J. I. Pena. 2009. "Credit Spreads: An Empirical Analysis on the Information 
Content of Stocks, Bonds, and CDS.” Journal of Banking and Finance, 33: 2012-2025.

Fung, H. G., G. E. Sierra, J. Yau, and G. Zhang. 2008. "Are the U.S. Stock Market and Credit Default Swap Market Related? Evidence from the CDX Indices." Journal of Alternative Investments, 11: 43-61.

Gibbons, R., and L. F. Katz. 1991. "Layoffs and Lemons." Journal of Labor Economics 9: 351380.

Graham, J.R., H. Kim, S. Li, and J. Qiu. 2013. "Human Capital Loss in Corporate Bankruptcy." Working paper, Duke University.

Gruber, J. 1997. "The Consumption Smoothing Benefits of Unemployment Insurance." American Economic Review, 87: 192-205.

Hennessy, C. A., and T. M. Whited. 2005. "Debt Dynamics." Journal of Finance, 60: 11291165.

Holzer, H. J., L. F. Katz, and A. B. Krueger. 1991. “Job Queues and Wages.” Quarterly Journal of Economics, 106: 739-768.

Hortascu, A., G. Matvos, C. Syverson, and S. Venkataraman. 2013. "Indirect Costs of Financial Distress in Durable Goods Industries: The Case of Auto Manufacturers." Review of Finance Studies, 26: 1248-1290.

Hotchkiss, E. S. 1995. "Post-Bankruptcy Performance and Management Turnover." Journal of Finance, 50: 3-21.

Hsu, J.W., D.A. Matsa, and B.T. Melzer. 2014. "Unemployment Insurance and Consumer Credit." Working paper, Northwestern University.

Jacobson, L. S., R. T. LaLonde, and D. G. Sullivan. 1993. "Earnings Losses of Displaced Workers." American Economic Review, 84: 685-709.

Jaggia, P. B., and A. V. Thakor. 1994. "Firm-Specific Human Capital and Optimal Capital Structure.” International Economic Review, 35: 283-308.

Jovanovic, B. 1979. "Firm-Specific Capital and Turnover." Journal of Political Economy, 87: $1246-1260$.

Kim, H. 2012. "Does Human Capital Specificity Affect Employer Capital Structure? Evidence from a Natural Experiment." Working paper, Duke University.

Kovenock, D., and G. M. Phillips. 1997. "Capital Structure and Product Market Behavior: An Examination of Plant Exit and Investment Decisions." Review of Financial Studies, 10: 767-803.

Kuhnen, C.M. 2011. "Searching for Jobs: Evidence from MBA Graduates." Working paper, Northwestern University. 
Lang, K. 1991. "Persistent wage dispersion and involuntary unemployment." Quarterly Journal of Economics 106: 181-202.

Lazear, E. P. 1979. “Why Is There Mandatory Retirement?" Journal of Political Economy, 87: $1261-1284$.

Longstaff, F. A., S. Mithal, and E. Neis. 2003. "The Credit-Default Swap Market: Is Credit Protection Priced Correctly?" Working paper, University of California at Los Angeles.

Lev, B. 1974. "On the Association between Operating Leverage and Risk." Journal of Financial and Quantitative Analysis, 9: 627-641.

Maksimovic, V., and S. Titman. 1991. "Financial Policy and Reputation for Product Quality." Review of Financial Studies, 4: 175-200.

Matsa, D. A. 2010. "Capital Structure as a Strategic Variable: Evidence from Collective Bargaining." Journal of Finance, 65: 1197-1232.

Matsa, D. A. 2011. "Running on Empty? Financial Leverage and Product Quality in the Supermarket Industry." American Economic Journal: Microeconomics, 3: 137-173.

Moffitt, R., and W. Nicholson. 1982. "The Effect of Unemployment Insurance on Unemployment: The Case of Federal Supplemental Benefits." Review of Economics and Statistics, 64: 1-11.

Montgomery, J.D. 1991. "Equilibrium wage dispersion and interindustry wage differentials." Quarterly Journal of Economics 106: 163-179.

Nicholson, W., and K. Needels. 2006. "Unemployment Insurance: Strengthening the Relationship between Theory and Policy." Journal of Economic Perspectives, 20: 47-70.

Norden, L., and M. Weber. 2009. "The Co-Movement of Credit Default Swap, Bond and Stock Markets: An Empirical Analysis.” European Financial Management, 15: 529-562.

Phillips, G. M. 1995. "Increased Debt and Industry Product Markets: An Empirical Analysis." Journal of Financial Economics, 37: 189-238.

Phillips, G., and G. Sertsios. 2013. "How Do Firm Financial Conditions Affect Product Quality and Pricing?" Management Science, forthcoming.

Pulvino, T. C. 1998. "Do Asset Fire Sales Exist? An Empirical Investigation of Commercial Aircraft Transactions.” Journal of Finance, 53: 939-978.

Rose, N. L. 1990. "Profitability and Product Quality: Economic Determinants of Airline Safety Performance." Journal of Political Economy, 98: 944-64.

Rosen. 1986. "The Theory of Equalizing Differences." In: O. Ashenfelter and R. Layard, editors: Handbook of Labor Economics, Volume 1, Great Britain: Elsevier, pp.641-692.

Sullivan, D. G., and T. von Wachter. 2009. "Job Displacement and Mortality: An Analysis Using 
Administrative Data." Quarterly Journal of Economics, 124: 1265-1306.

Sverke, M., and J. Hellgren. 2002. "The Nature of Job Insecurity: Understanding Employment Uncertainty on the Brink of the New Millennium." Applied Psychology, 51: 23-42.

Titman, S. 1984. "The Effect of Capital Structure on a Firm's Liquidation Decision.” Journal of Financial Economics, 13: 137-151.

Topel, R. 1984. "Equilibrium Earnings, Turnover, and Unemployment: New Evidence.” Journal of Labor Economics, 2: 500-522.

Topel, R. 1991. "Specific Capital, Mobility, and Wages: Wages Rise with Job Seniority." Journal of Political Economy, 99: 145-176.

Topel, R. H., and M. P. Ward. 1992. "Job Mobility and the Careers of Young Men." Quarterly Journal of Economics, 107: 439-79.

Zingales, L. 1998. "Survival of the Fittest or the Fattest? Exit and Financing in the Trucking Industry." Journal of Finance, 53: 905-938. 
Panel A: All firms

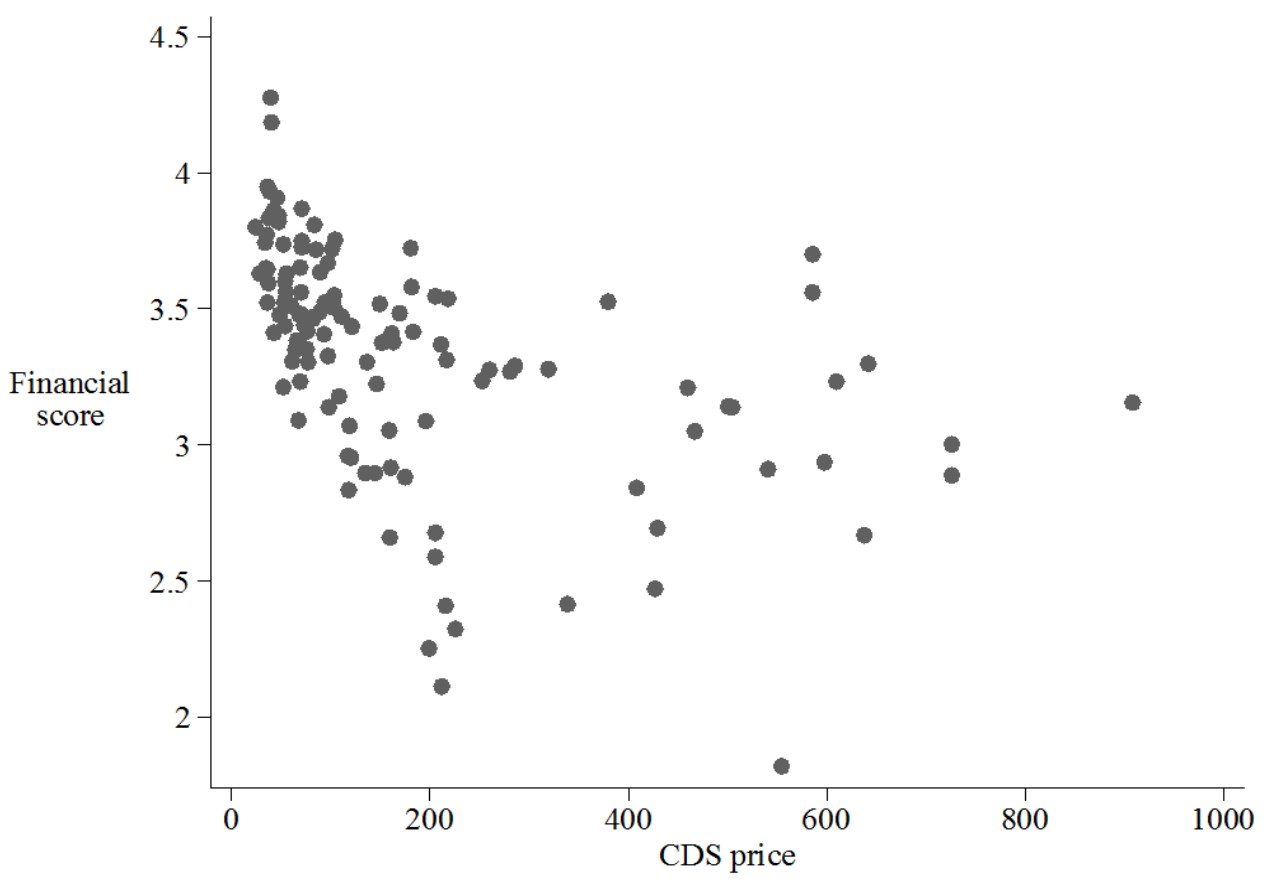

Panel B: Firms in the financial services industry

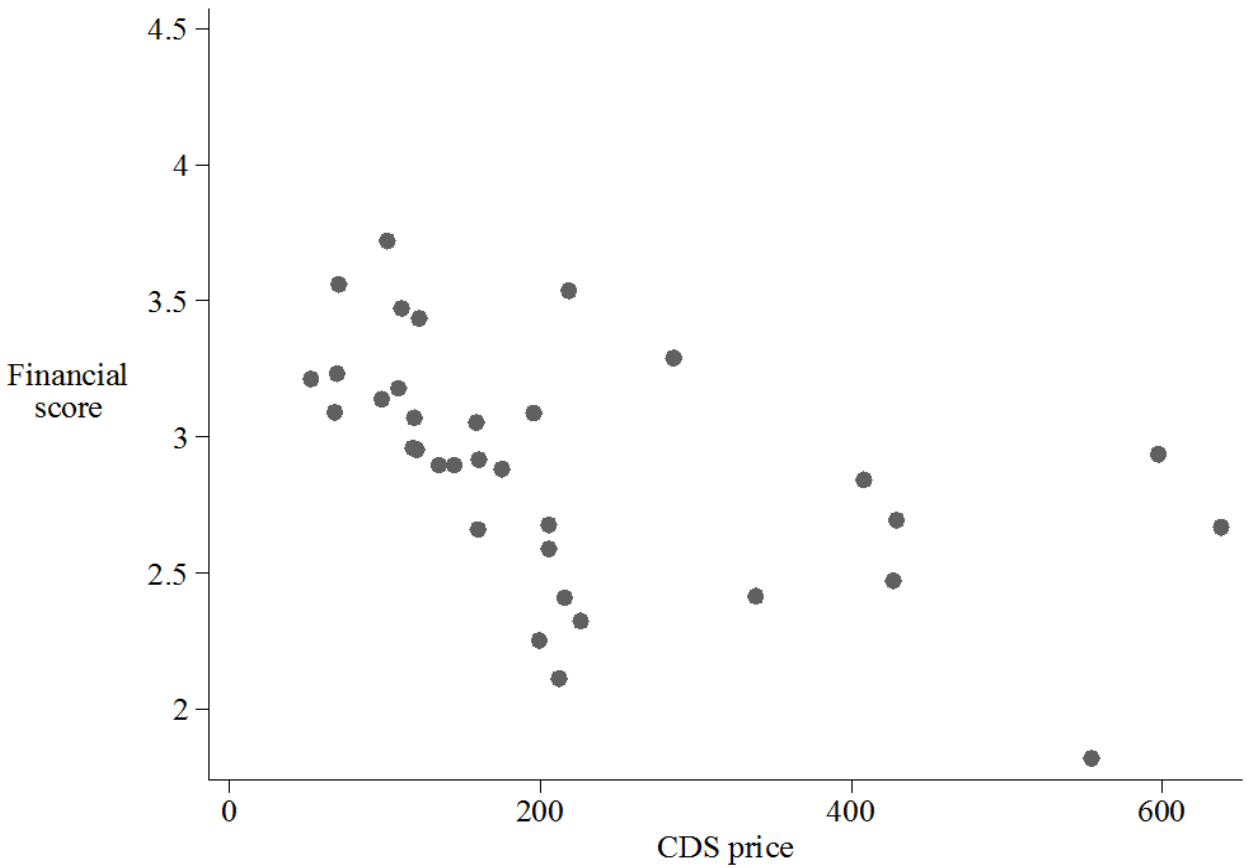

Figure 1. Firms' Financial Scores and CDS Prices. The figure plots firms' average financial score, assigned by the surveyed job seekers on a 5-point scale where " 1 " indicates strong disagreement and " 5 " indicates strong agreement with the statement that a given firm is a "financially strong organization," against firms' credit default swap (CDS) price in basis points of the insured value on the survey date. Panel A includes 126 observations for which survey data and CDS prices are available; Panel B includes only the 37 of those observations that are for firms in the financial services industry. To conceal firms' identities, this figure includes only firms with CDS prices below 1,000 basis points. 


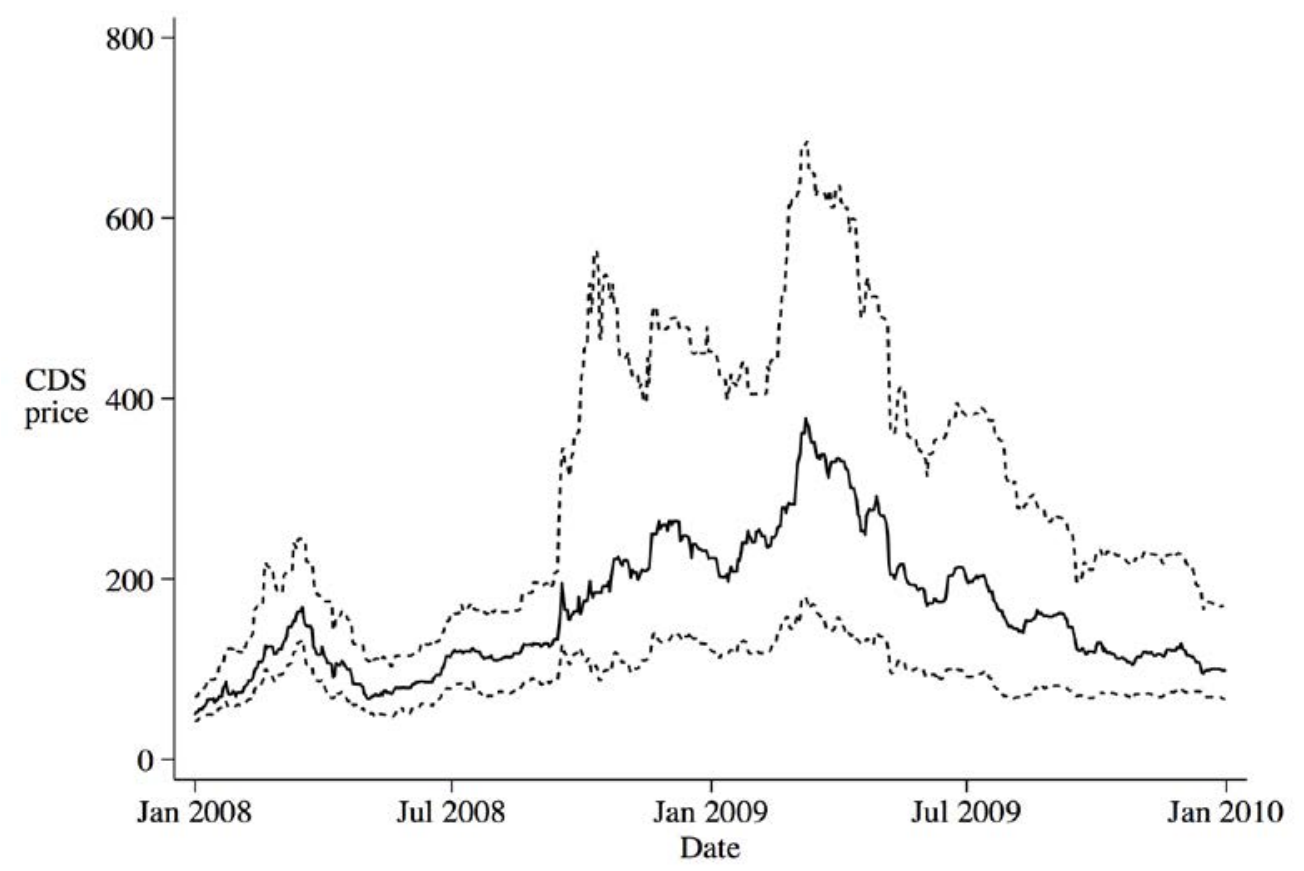

Figure 2. Daily CDS Prices for Large Financial Services Firms, 2008-2009. The figure reports the 25th percentile, median, and 75th percentile daily credit default swap (CDS) prices for the 78 firms in the financial services industry (including banks, investment firms and insurance companies) with total assets in excess of $\$ 25$ billion and for which CDS prices are available. CDS price is in basis points of insured value.

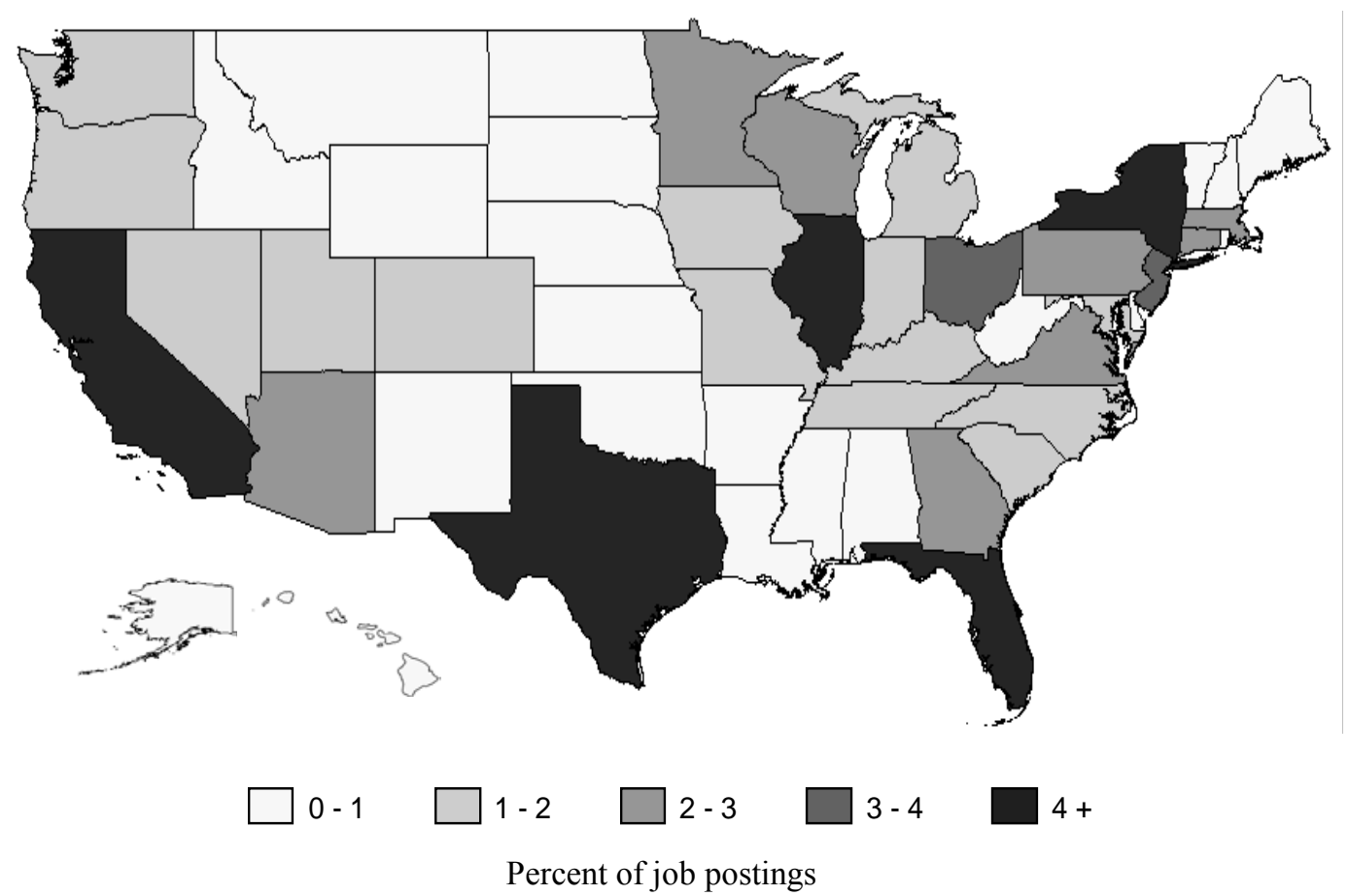

Figure 3. Distribution of Job Postings By State. This figure displays the geographic distribution of job postings. The positions, many of which are in retail branches, are spread across all fifty U.S. states roughly in proportion to population. 


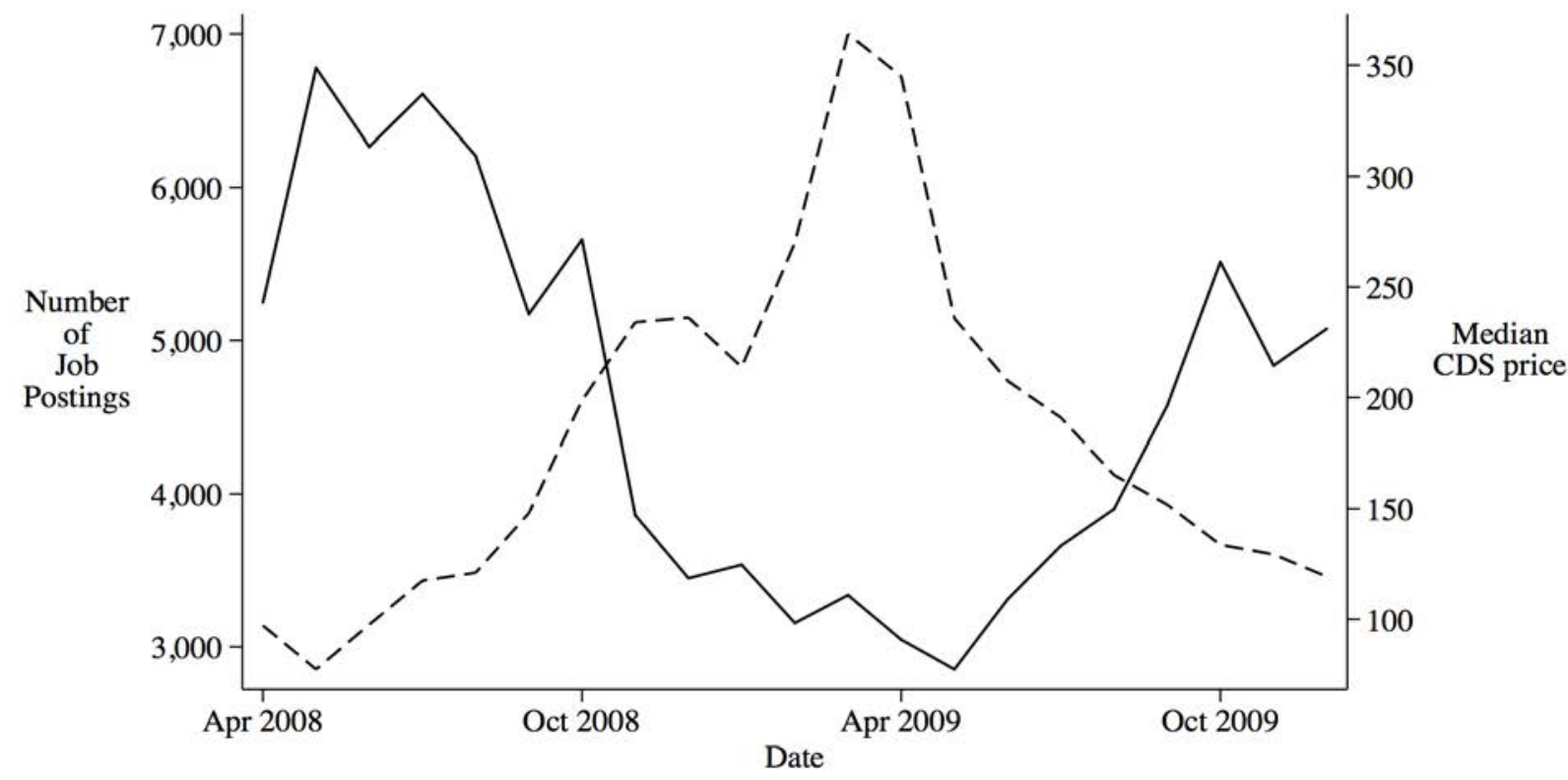

- Number of Job Postings $\quad-----$ Median CDS Price

Figure 4. Job Postings and CDS prices, April 2008-December 2009. This figure plots the total number of jobs posted to the online platform each month by the 40 sample financial services firms and their median credit default swap (CDS) price in basis points of insured value.

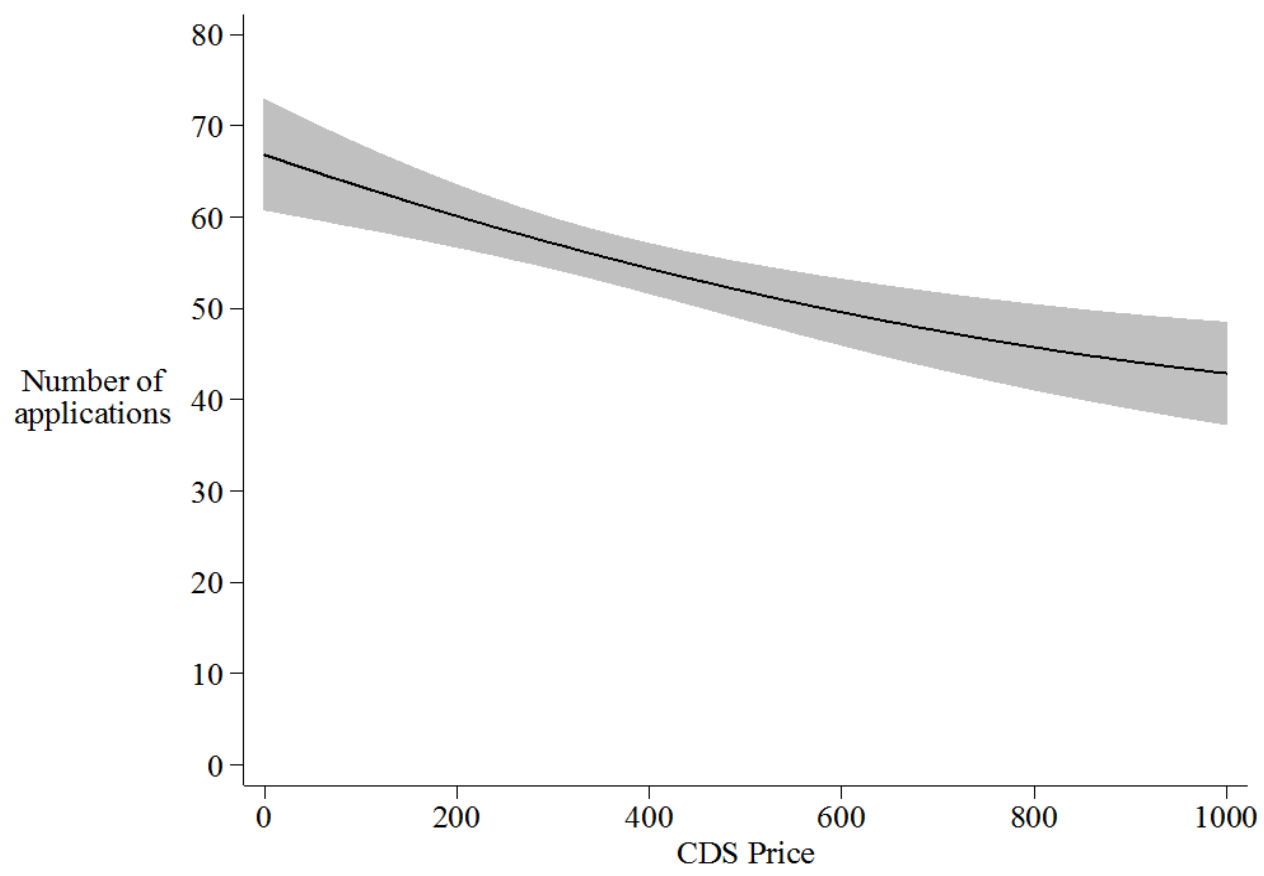

Figure 5. Number of applications and CDS Prices in October 2008. This figure plots the predicted number of applications per job posting in October 2008 as a quadratic function of the credit default swap (CDS) price in basis points of insured value. The shaded area represents the $95 \%$ confidence interval for the prediction. 


\section{Table 1}

\section{Survey Summary Statistics}

This table reports summary statistics for the survey sample. The surveys, which were conducted by a large online job search platform between October 2008 and March 2010, asked respondents to assign a score on a 5-point scale where " 1 " indicates strong disagreement and " 5 " indicates strong agreement with the statement that a given firm is a "financially strong organization." Firms' average financial score is merged with daily credit default swap (CDS) prices from Bloomberg and with accounting and industry information from Compustat. The accounting variables are for Q1 of 2008, and industries are classified based on firms' 2-digit NAICS codes.

\section{Panel A: Surveys and respondents}

\begin{tabular}{lcccc}
\hline \# of unique firms & 145 & & \\
\# of observations & 194 & & \\
\# of observations with CDS prices & 126 & & \\
\cline { 1 - 2 } & & & Mean & Std. dev. \\
\cline { 2 - 3 } \# of respondents & 194 & 150.7 & 91.6 \\
Financial score (5-point scale) & 194 & 3.3 & 0.4 \\
CDS price in basis points & 126 & & 319 \\
\hline
\end{tabular}

Panel B: Firms in surveys (2008Q1)

\begin{tabular}{lccc}
\hline & \# of obs. & Mean & Std. dev. \\
\cline { 2 - 4 } Market cap (\$ million) & 124 & 31,974 & 54,067 \\
Return on assets (\%) & 122 & 2.05 & 1.98 \\
Sales growth (\%) & 134 & 11.16 & 25.83 \\
Market-to-book ratio & 124 & 1.65 & 0.81 \\
Debt / Total assets & 125 & 0.29 & 0.21 \\
\hline
\end{tabular}

Panel C: Industry breakdown for survey firms

\begin{tabular}{lc}
\cline { 2 - 2 } Accommodation and food services & 10 \\
Administrative and Support Services & 4 \\
Construction & 3 \\
Finance and insurance & 30 \\
Health care and social assistance & 8 \\
Information & 17 \\
Manufacturing & 33 \\
Other & 2 \\
Professional, scientific and technical services & 10 \\
Real estate, rental, and leasing & 4 \\
Retail trade & 15 \\
Transportation and warehousing & 5 \\
Wholesale trade & 4
\end{tabular}


Table 2

Firms' Financial Score and CDS Prices

The table summarizes the results from regressions of firms' average financial score assigned by the surveyed job seekers on the firms' credit default swap (CDS) price. Where indicated, the regressions include controls for industry (3-digit NAICS) and quarter fixed effects. CDS prices are measured in decimal form (i.e., 10,000 basis points) on the survey date. The analysis reported in Panel A includes all firms, and the analysis reported in Panel B includes only firms in the financial services industry. Robust standard errors are reported in parentheses. $* * *$ indicates statistical significance at the $1 \%$ level.

\section{Panel A: All firms}

Dependent variable: Average financial score

\begin{tabular}{ccccc} 
& $2 . \mathrm{A}$ & $2 . \mathrm{B}$ & $2 . \mathrm{C}$ & $2 . \mathrm{D}$ \\
\cline { 2 - 5 } CDS price & $-5.32^{* * *}$ & $-5.48^{* * *}$ & $-5.77^{* * *}$ & $-6.06^{* * *}$ \\
& $(1.54)$ & $(1.32)$ & $(1.55)$ & $(1.14)$
\end{tabular}

Fixed effects

Industry

$\mathrm{X}$

$\mathrm{X}$

Quarter

$\begin{array}{ll} & X \\ X & X\end{array}$

$R^{2}$

0.16

0.63

0.27

0.67

$N$

126

126

126

126

Panel B: Firms in the financial services industry

\begin{tabular}{lcccc}
\hline \multicolumn{2}{c}{ Dependent variable: } & Average financial score & & \\
& $2 . \mathrm{E}$ & $2 . \mathrm{F}$ & $2 . \mathrm{G}$ & $2 . \mathrm{H}$ \\
\cline { 2 - 5 } CDS price & $-7.38^{* * *}$ & $-7.46^{* * *}$ & $-9.39^{* * *}$ & $-9.36^{* * *}$ \\
& $(2.32)$ & $(2.77)$ & $(1.96)$ & $(2.38)$ \\
& & & & \\
Fixed effects & & $\mathrm{X}$ & & $\mathrm{X}$ \\
$\quad$ Industry & & & $\mathrm{X}$ & $\mathrm{X}$ \\
$\quad$ Quarter & & & & \\
& 0.23 & 0.30 & 0.35 & 0.41 \\
$R^{2}$ & 37 & 37 & 37 & 37 \\
$N$ & & &
\end{tabular}


Table 3

Firms' Financial Score and Accounting Performance

The table summarizes the results from regressions of firms' average financial score assigned by the surveyed job seekers on the firms' one-quarter lagged return on assets, lagged sales growth, lagged market-to-book ratio, and/or credit default swap (CDS) price. All regressions include controls for industry (3-digit NAICS) and quarter fixed effects. CDS prices are measured in decimal form (i.e., 10,000 basis points) on the survey date. The analysis reported in Panel A includes all firms, and the analysis reported in Panel B includes only firms in the financial services industry. Robust standard errors are reported in parentheses. *, **, and *** indicate statistical significance at the $10 \%, 5 \%$, and $1 \%$ levels, respectively.

Panel A: All firms

\begin{tabular}{|c|c|c|c|c|}
\hline \multicolumn{5}{|c|}{ Dependent variable: Average financial score } \\
\hline & 3.A & 3.B & 3.C & 3.D \\
\hline Return on assets (lagged 1 quarter) & $\begin{array}{l}2^{2.69} \text { *** } \\
(0.76)\end{array}$ & & & $\begin{array}{l}2^{2.66^{* * *}} \\
(0.67)\end{array}$ \\
\hline Sales growth (lagged 1 quarter) & & $\begin{array}{l}0.29 * \\
(0.14)\end{array}$ & & \\
\hline Market-to-book ratio (lagged 1 quarter) & & & $\begin{array}{l}0.17^{* * * *} \\
(0.05)\end{array}$ & \\
\hline CDS price & & & & $\begin{array}{l}-5.32 \text { *** } \\
(0.95)\end{array}$ \\
\hline \multicolumn{5}{|l|}{ Fixed effects } \\
\hline Industry & X & X & $X$ & $X$ \\
\hline Quarter & $\mathrm{X}$ & $\mathrm{X}$ & $\mathrm{X}$ & $\mathrm{X}$ \\
\hline$R^{2}$ & 0.58 & 0.53 & 0.52 & 0.78 \\
\hline$N$ & 162 & 180 & 167 & 103 \\
\hline
\end{tabular}

Panel B: Firms in the financial services industry

Dependent variable: Average financial score

Return on assets (lagged 1 quarter)

\begin{tabular}{cccc}
$3 . \mathrm{E}$ & $3 . \mathrm{F}$ & $3 . \mathrm{G}$ & $3 . \mathrm{H}$ \\
\hline $23.28^{* * *}$ & & & $24.08^{* *}$ \\
$(4.77)$ & & & $(8.64)$
\end{tabular}

Sales growth (lagged 1 quarter)

Market-to-book ratio (lagged 1 quarter)

CDS price

Fixed effects

Industry

Quarter

$\begin{array}{llll}X & X & X & X \\ X & X & X & X\end{array}$

$R^{2}$

0.50

0.41

0.45

0.62

N

45

55

47 
Table 4

Application Summary Statistics

This table reports summary statistics for the application sample. The sample includes applications to 96,065 jobs at 40 large financial services firms between April 2008 and December 2009. The sample includes all financial services firms with total assets exceeding \$25 billion and for which both job applications data and credit default swap (CDS) prices are available. CDS price is the average price for the calendar month in which the job was first posted.

\begin{tabular}{|c|c|c|c|c|}
\hline \# of firms & 40 & & & \\
\hline \# of weeks of available data & 91 & & & \\
\hline \# of job postings & 96,065 & & & \\
\hline & \# of obs. & Mean & Std. dev. & Median \\
\hline \# of jobs posted per firm over all weeks & 40 & $2,401.6$ & $3,687.5$ & 659 \\
\hline \# of jobs posted per week & 91 & $1,055.7$ & 330.6 & 976 \\
\hline \# of jobs posted per firm per week & 2,552 & 37.6 & 60.4 & 14 \\
\hline \# of applications per job posting & 96,065 & 57.7 & 111.1 & 28 \\
\hline \# of applications per firm over all weeks & 40 & $138,646.8$ & $186,764.8$ & 46,191 \\
\hline CDS price in basis points & 96,065 & 237 & 276 & 156 \\
\hline
\end{tabular}




\section{Table 5}

CDS Prices and Applicant Counts

The table summarizes the results from regressions of the log number of applications for an open position on the posting firm's credit default swap (CDS) price. All regressions include firm fixed effects. Where indicated, regressions also include fixed effects for month, state, state-month, job type, detailed job type, and/or detailed job type-state-month. Each position is assigned up to 4 of 19 job types and 1 of 679 detailed job types. CDS prices are measured in decimal form (i.e., 10,000 basis points). Standard errors, adjusted for clustering at the firm level, are reported in parentheses. $* *$ and $* * *$ indicate statistical significance at the $5 \%$ and $1 \%$ levels, respectively.

Dependent variable: $\ln$ (\# of applications)

CDS price

\begin{tabular}{cccccc} 
5.A & $5 . \mathrm{B}$ & $5 . \mathrm{C}$ & $5 . \mathrm{D}$ & $5 . \mathrm{E}$ & $5 . \mathrm{F}$ \\
\hline$-1.937 * *$ & $-1.784 * *$ & $-1.745 * * *$ & $-1.733 * * *$ & $-1.337 * * *$ & $-2.372 * * *$ \\
$(0.833)$ & $(0.720)$ & $(0.655)$ & $(0.646)$ & $(0.466)$ & $(0.833)$
\end{tabular}

Fixed effects

Firm

Month

State

State-Month

Job type

Detailed job type

Detailed job type-State-Month

$\begin{array}{ll}X & X \\ X & X \\ & X\end{array}$

$R^{2}$

0.18

96,065

N

96,065

X

X

X

$X$
$X$

X

0.27

0.35

96,065

0.40

96,065

0.63

96,065

96,065

X

X

X

X 


\section{Table 6}

\section{Alternative Specifications}

The table summarizes the results from regressions of the number of applications for an open position (measured in logs or levels) on the posting firm's average financial score assigned by the surveyed job seekers, credit default swap (CDS) price (measured in levels or as a step function), or log stock price. When indicated, regressions include firm fixed effects and either detailed job type-state-month or detailed job type-MSA-month fixed effects. Average financial score is the mean score in a quarter in which the firm was the subject of a survey. The stock price is the closing stock price for the calendar month in which the job was first posted. In column 6.C, the CDS price indicators measure differences relative to firms with a CDS price below the 25th percentile. CDS prices are measured in decimal form (i.e., 10,000 basis points). Standard errors, adjusted for clustering at the firm level, are reported in parentheses. *, **, and *** indicate statistical significance at the $10 \%, 5 \%$, and $1 \%$ levels, respectively.

\begin{tabular}{|c|c|c|c|c|c|}
\hline \multirow[t]{2}{*}{ Dependent variable: } & \multicolumn{4}{|c|}{ In(\# of applications) } & \multirow{2}{*}{$\begin{array}{c}\text { \# of applications } \\
6 . \mathrm{E} \\
\end{array}$} \\
\hline & 6.A & 6.B & 6.C & 6.D & \\
\hline Average financial score & $\begin{array}{l}0.843 \text { * } \\
(0.434)\end{array}$ & & & & \\
\hline $\ln ($ Stock price $)$ & & $\begin{array}{l}0.198^{* * *} \\
(0.045)\end{array}$ & & & \\
\hline CDS price 25 th to 50 th percentile & & & $\begin{array}{r}-0.047 \\
(0.070)\end{array}$ & & \\
\hline CDS price 50 th to 75 th percentile & & & $\begin{array}{r}-0.090 \\
(0.116)\end{array}$ & & \\
\hline CDS price 75 th to 95 th percentile & & & $\begin{array}{l}-0.259 * \\
(0.146)\end{array}$ & & \\
\hline CDS price $\geq 95$ th percentile & & & $\begin{array}{l}-0.499 * * * \\
(0.177)\end{array}$ & & \\
\hline CDS price & & & & $\begin{array}{l}-2.380 * * \\
(1.147)\end{array}$ & $\begin{array}{l}-56.089 * \\
(31.519)\end{array}$ \\
\hline Fixed effects & & & & & \\
\hline Firm & & $\mathrm{X}$ & $\mathrm{X}$ & $\mathrm{X}$ & $\mathrm{X}$ \\
\hline Detailed job type-State-Month & $\mathrm{X}$ & $\mathrm{X}$ & $\mathrm{X}$ & & $\mathrm{X}$ \\
\hline Detailed job type-MSA-Month & & & & $\mathrm{X}$ & \\
\hline$R^{2}$ & 0.67 & 0.64 & 0.63 & 0.74 & 0.63 \\
\hline$N$ & 8,872 & 84,763 & 96,065 & 94,771 & 96,065 \\
\hline
\end{tabular}


Table 7

\section{Economic vs. Financial Distress}

The table summarizes the results from regressions of the log number of applications for an open position on measures of firms' financing and/or performance. In the first six columns, the log number of applications is regressed on a measure of firms' financing and its interaction with the monthly median credit default swap (CDS) price in the industry. The measures of firms' financing are the ratio of debt to total assets in 2008Q1 (Column 7.A), an indicator for when this leverage ratio is greater than 0.51 (Column 7.B), the ratio of current debt to total debt at year-end 2007 (Column 7.C), an indicator for when this current debt ratio is greater than 0.1 (Column 7.D), the fraction of firms' syndicated loans with a covenant (weighted by the initial amount of the loan in US dollars; Column 7.E), and an indicator for when this fraction is greater than 0.2 (Column 7.F). Industry CDS prices are the median price over a month for firms in the financial services industry (including banks, investment firms and insurance companies) with total assets in excess of $\$ 25$ billion and for which CDS prices are available (see Figure 2). The industry median CDS price is demeaned with respect to its sample mean (156 basis points) before it is interacted with the measures of firms' financing. In the last two columns, the log number of applications is regressed on the posting firm's CDS price and contemporaneous and lagged quarterly return on assets, where the CDS price is the average price over the month (Column 7.G) or quarter (Column 7.H) in which the job was posted. All regressions include firm and detailed job type-state-month fixed effects. All CDS prices are measured in decimal form (i.e., 10,000 basis points). Standard errors, adjusted for clustering at the firm level, are reported in parentheses. $* *$ and *** indicate statistical significance at the $5 \%$ and $1 \%$ levels, respectively. 
Table 7 - continued

Economic vs. Financial Distress

\section{Dependent variable:}

Debt-to-assets ratio (2008Q1) $\times$ Industry median CDS price

1[> Top quartile debt-to-assets (2008Q1)] $\times$ Industry median CDS price

Current debt / Total debt

(Current debt / Total debt)

$\times$ Industry median CDS price

1[Current Debt / Total debt $>0.1]$

1[Current Debt / Total debt $>0.1]$

$\times$ Industry median CDS price

(Fraction of syndicated loans with covenants)

$\times$ Industry median CDS price

1(Fraction of syndicated loans with covenants $>0.2$ )

$\times$ Industry median CDS price

CDS price

Mean CDS price over quarter

ROA

ROA lagged by one quarter

\section{Fixed effects}

Firm

Detailed job type-State-Month
In(\# of applications)

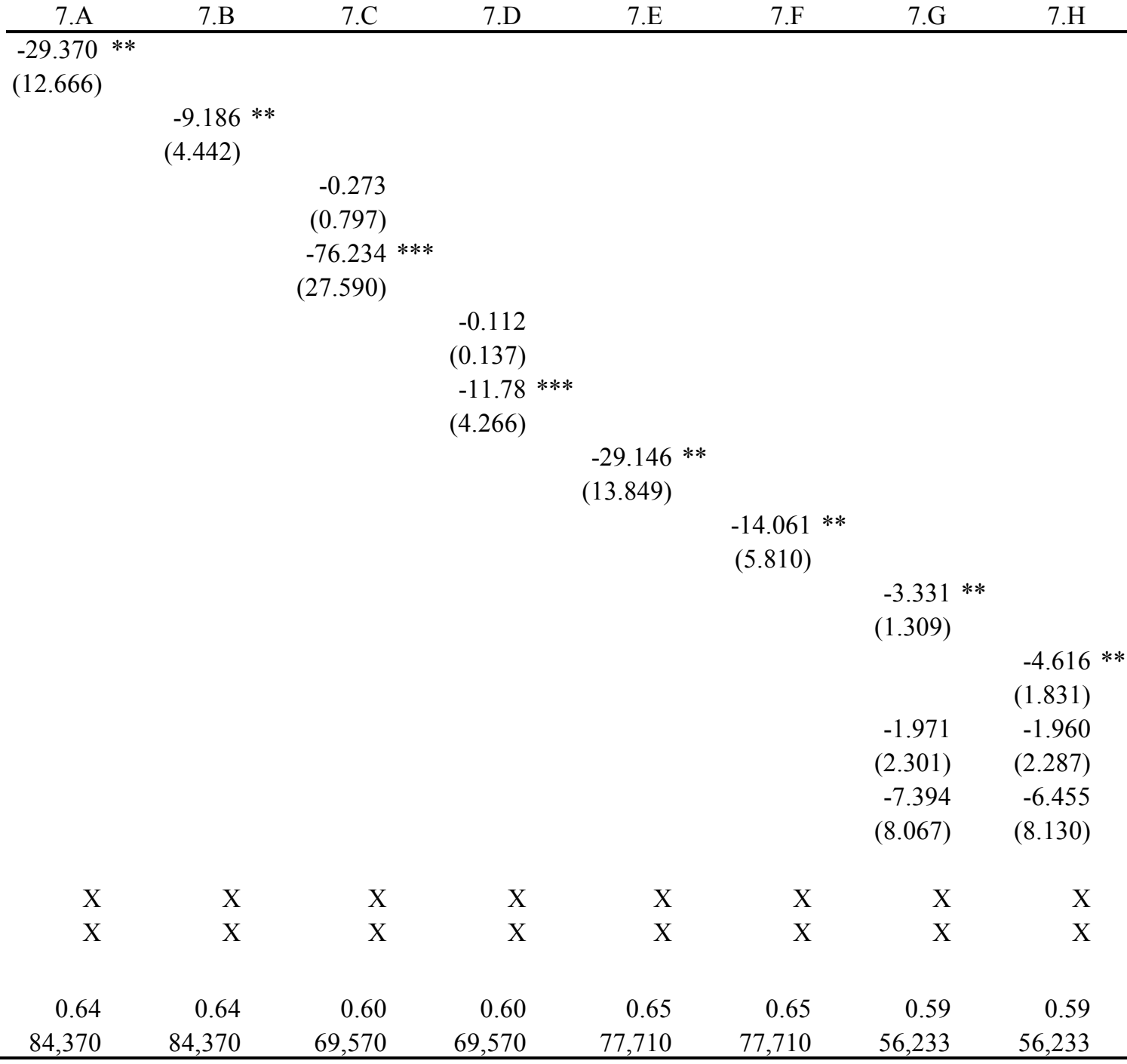


Table 8

CDS Prices, Applicant Counts, and Salaries

The table summarizes the results from regressions of the log number of applications or the log annual salary for an open position on the posting firm's credit default swap (CDS) price. Where indicated, regressions include fixed effects for firm, month, state-month, job title, firm-job title, and/or firm-state-job title. CDS prices are measured in decimal form (i.e., 10,000 basis points). Standard errors, adjusted for clustering at the firm level, are reported in parentheses. *, **, and *** indicate statistical significance at the $10 \%, 5 \%$, and $1 \%$ levels, respectively.

Dependent variable: $\ln (\#$ of applications)

CDS price

\begin{tabular}{ccc}
$8 . \mathrm{A}$ & $8 . \mathrm{B}$ & $8 . \mathrm{C}$ \\
\hline$-1.125 * *$ & $-0.962 * *$ & $-1.045 * * *$ \\
$(0.470)$ & $(0.489)$ & $(0.416)$
\end{tabular}

In(Annual salary)

\begin{tabular}{crr}
$8 . \mathrm{D}$ & $8 . \mathrm{E}$ & $8 . \mathrm{F}$ \\
\hline $1.792 *$ & $1.738 *$ & 1.569 \\
$(0.946)$ & $(0.911)$ & $(1.050)$
\end{tabular}

Fixed effects

Firm $\mathrm{X}$

Month

State-Month

Job title

Firm-Job title

Firm-State-Job title

$\mathrm{X}$

X
$R^{2}$

N

96,065

X

X
X

X

X

X 
Table 9

Role of Unemployment Insurance

The table summarizes the results from regressions of the log number of applications or the log annual salary for an open position on the posting firm's credit default swap (CDS) price and the interaction between the CDS price and the log of the prevailing maximum unemployment insurance (UI) benefit in the state where the job is located. All regressions include firm fixed effects. Where indicated, regressions also include fixed effects for month, state, state-month, job type, detailed job type, and/or detailed job type-state-month. CDS prices are measured in decimal form (i.e., 10,000 basis points). Max UI benefit is the state-specific maximum that a recipient can receive under normal conditions for a single unemployment spell; the sample mean is subtracted from the variable before it is interacted with the CDS price. Although not reported in the table, the regression reported in column 9.A controls for the log of the prevailing maximum UI benefit (not interacted); in all other specifications, that estimate is absorbed by the state fixed effects. Standard errors, adjusted for clustering at the firm level, are reported in parentheses. ${ }^{* *}$ and $* * *$ indicate statistical significance at the $5 \%$ and $1 \%$ levels, respectively.

Dependent variable:

In(\# of applications)

$\ln$ (Annual salary)

CDS price

\begin{tabular}{ccccccc}
$9 . \mathrm{A}$ & $9 . \mathrm{B}$ & $9 . \mathrm{C}$ & $9 . \mathrm{D}$ & $9 . \mathrm{E}$ & $9 . \mathrm{F}$ & $9 . \mathrm{G}$ \\
\hline$-1.915^{* *}$ & $-1.773^{* *}$ & $-1.706^{* * *}$ & $-1.693^{* * *}$ & $-1.300^{* * *}$ & $-2.233^{* * *}$ & $12.775^{* *}$ \\
$(0.829)$ & $(0.738)$ & $(0.663)$ & $(0.656)$ & $(0.472)$ & $(0.872)$ & $(5.949)$ \\
$2.915^{* *}$ & $2.982^{* *}$ & $4.857^{* * *}$ & $4.878^{* * *}$ & $4.674^{* * *}$ & $4.554 * * *$ & $-38.499^{* *}$ \\
$(1.320)$ & $(1.320)$ & $(1.416)$ & $(1.239)$ & $(1.144)$ & $(1.426)$ & $(17.068)$
\end{tabular}

Fixed effects

Firm

Month

State

State-Month

Job type

Detailed job type

Detailed job type-State-Month

$\begin{array}{ll}X & X \\ X & X \\ & X\end{array}$

$\mathrm{X}$
$\mathrm{X}$
$\mathrm{X}$

$\mathrm{X}$

X

$\mathrm{X}$

$\mathrm{X}$

X

$\mathrm{X}$

$\mathrm{X}$

$\mathrm{X}$

$R^{2}$

$N$

0.19

0.26

96,059

96,059

0.27

0.35

96,059

96,059

0.40

96,059

6.63

X X

$\mathrm{X}$ 


\section{Table 10}

CDS Prices and Applicants' Location

The table summarizes the results from regressions of the proportion of applications received from out of state on the posting firm's credit default swap (CDS) price. All regressions include firm fixed effects. Where indicated, regressions also include fixed effects for month, state, state-month, job type, detailed job type, and/or detailed job type-state-month. CDS prices are measured in decimal form (i.e., 10,000 basis points). Regressions include only jobs for which we observe location information for more than $80 \%$ of applications and are weighted by the number of applications for which we observe location information. Standard errors, adjusted for clustering at the firm level, are reported in parentheses. $*, * *$, and $* * *$ indicate statistical significance at the $10 \%, 5 \%$, and $1 \%$ levels, respectively.

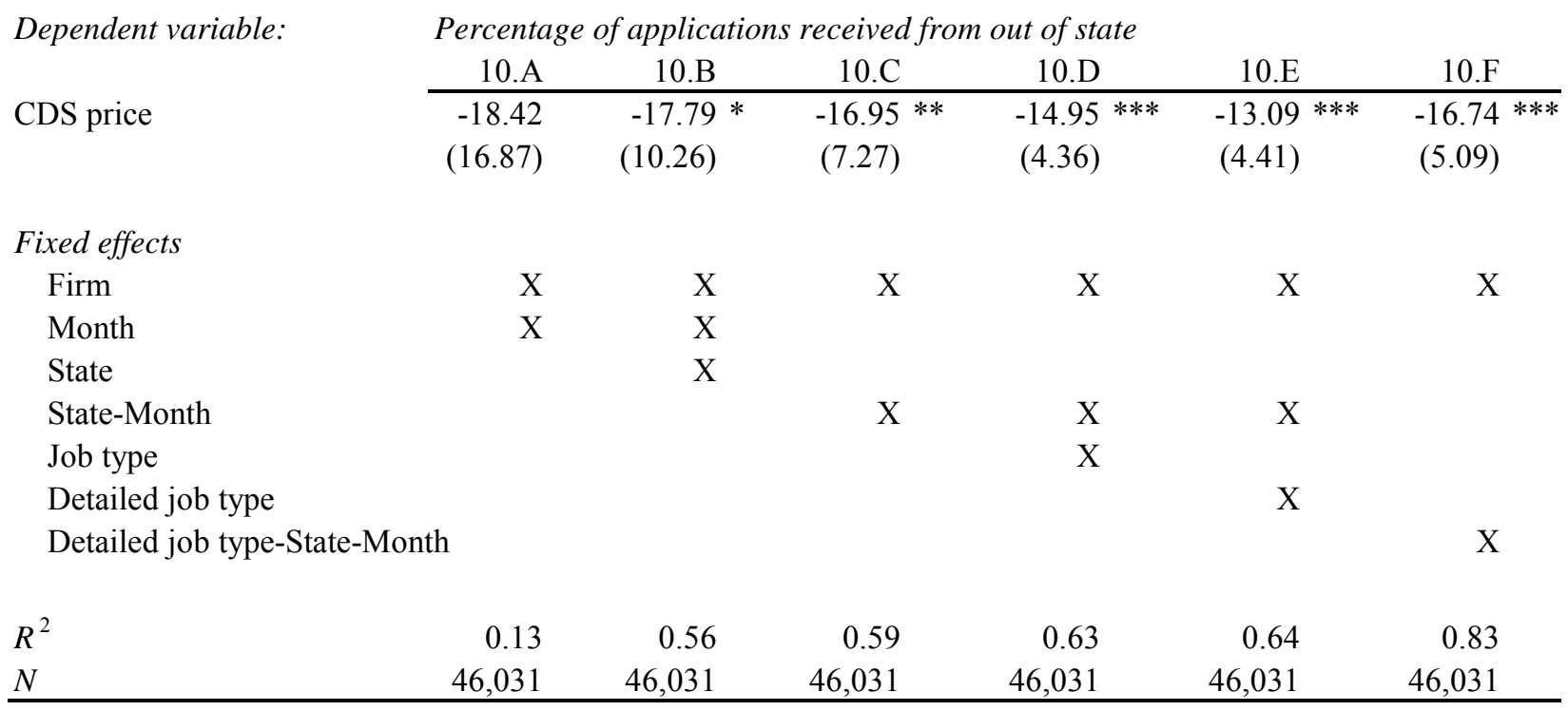


Table 11

\section{CDS Prices and Applicant Pool}

The table summarizes the results from regressions of characteristics of the applicant pool on the posting firm's credit default swap (CDS) price. All regressions include firm and detailed job type-state-month fixed effects. CDS prices are measured in decimal form (i.e., 10,000 basis points). Applicant pool characteristics are based on ZIP code demographics from the 2000 United States Census. Regressions include only jobs for which we observe Census information for more than $80 \%$ of applications and are weighted by the number of applications for which we observe Census information. Standard errors, adjusted for clustering at the firm level, are reported in parentheses. *, **, and $* * *$ indicate statistical significance at the $10 \%, 5 \%$, and $1 \%$ levels, respectively.

\begin{tabular}{|c|c|c|c|c|}
\hline Dependent variable: & $\begin{array}{c}\text { In(Average } \\
\text { applicant ZIP code } \\
\text { earnings) }\end{array}$ & $\begin{array}{l}\text { In(Median applicant } \\
\text { ZIP code earnings) }\end{array}$ & $\begin{array}{c}\text { Average percentage } \\
\text { of applicant ZIP } \\
\text { code with 4-year } \\
\text { college degree }\end{array}$ & $\begin{array}{c}\text { Median percentage } \\
\text { of applicant ZIP } \\
\text { code with 4-year } \\
\text { college degree }\end{array}$ \\
\hline & 11.A & 11.B & 11.C & 11.D \\
\hline Standard deviation of dependent variable & 0.15 & 0.15 & 6.04 & 6.94 \\
\hline CDS price & $\begin{array}{l}-0.18 * \\
(0.11)\end{array}$ & $\begin{array}{l}-0.23^{* *} \\
(0.10)\end{array}$ & $\begin{array}{l}-7.24 * \\
(4.12)\end{array}$ & $\begin{array}{l}-11.49^{* * *} \\
(4.08)\end{array}$ \\
\hline \multicolumn{5}{|l|}{ Fixed effects } \\
\hline Firm & $\mathrm{X}$ & $\mathrm{X}$ & $\mathrm{X}$ & $X$ \\
\hline Detailed job type-State-Month & $\mathrm{X}$ & $X$ & $X$ & $X$ \\
\hline$R^{2}$ & 0.76 & 0.73 & 0.74 & 0.71 \\
\hline$N$ & 35,883 & 35,883 & 35,883 & 35,883 \\
\hline
\end{tabular}




\section{Table 12}

\section{CDS Prices and Applicant Counts by Required Education}

The table summarizes the results from regressions of the log number of applications for an open position on the posting firm's credit default swap (CDS) price. All regressions include firm fixed effects. Where indicated, regressions also include fixed effects for state-month, job type, detailed job type, and/or detailed job type-statemonth. CDS prices are measured in decimal form (i.e., 10,000 basis points). Regressions reported in columns 12.A through 12.C include only jobs that require a high school education or less; and regressions reported in columns 12.D through 12.F include only jobs that require a 4-year college degree. Standard errors, adjusted for clustering at the firm level, are reported in parentheses. ${ }^{*}$ and $* *$ indicate statistical significance at the $10 \%$ and $5 \%$ levels, respectively.

\begin{tabular}{|c|c|c|c|c|c|c|}
\hline \multirow[t]{3}{*}{ Dependent variable: } & \multicolumn{6}{|c|}{ In(\# of applications) } \\
\hline & \multicolumn{3}{|c|}{ Jobs requiring high school or less } & \multicolumn{3}{|c|}{ Jobs requiring 4 -year college degree } \\
\hline & 12.A & 12.B & 12.C & 12.D & 12.E & 12.F \\
\hline CDS price & $\begin{array}{l}-0.518 \\
(1.537)\end{array}$ & $\begin{array}{r}1.106 \\
(1.029)\end{array}$ & $\begin{array}{l}-2.288 \\
(2.121)\end{array}$ & $\begin{array}{l}-2.091 * \\
(1.129)\end{array}$ & $\begin{array}{l}-2.808 \text { ** } \\
(1.246)\end{array}$ & $\begin{array}{l}-2.583 \text { ** } \\
(1.313)\end{array}$ \\
\hline \multicolumn{7}{|l|}{ Fixed effects } \\
\hline Firm & $\mathrm{X}$ & $\mathrm{X}$ & $\mathrm{X}$ & $\mathrm{X}$ & $\mathrm{X}$ & $\mathrm{X}$ \\
\hline State-Month & $\mathrm{X}$ & $\mathrm{X}$ & & $\mathrm{X}$ & $\mathrm{X}$ & \\
\hline Job type & $\mathrm{X}$ & & & $\mathrm{X}$ & & \\
\hline Detailed job type & & $\mathrm{X}$ & & & $\mathrm{X}$ & \\
\hline Detailed job type-S & & & $\mathrm{X}$ & & & $\mathrm{X}$ \\
\hline$R^{2}$ & 0.32 & 0.41 & 0.65 & 0.38 & 0.42 & 0.65 \\
\hline$N$ & 11,802 & 11,802 & 11,802 & 25,193 & 25,193 & 25,193 \\
\hline
\end{tabular}




\section{Table 13}

CDS Prices, Employment Changes, and the Volume of Job Postings

Columns 13.A and 13.B summarize the results from cross-sectional regressions of a firm's change in employment between December 31, 2007, and December 31, 2009, on its maximum credit default swap (CDS) price over that period. The dependent variable is the percent change in employment in column 13.A and an indicator for an employment reduction in column 13.B; both regressions exclude two privately held firms for which employment data are not available. Column 13.C reports results from a cross-sectional regression of the log total number of jobs a firm posted between April 1, 2008, and December 31, 2009, on its maximum credit default swap (CDS) price over that period. Columns 13.D and 13.E report results from firm-month panel regressions of job postings on the posting firm's CDS price. The dependent variable is an indicator for any postings in column 13.D and the log number of postings, if any, in column 13.E. Both regressions include firm and month fixed effects. In all five specifications, CDS prices are measured in decimal form (i.e., 10,000 basis points). Robust standard errors, adjusted for clustering at the firm level in columns 13.D and 13.E, are reported in parentheses. * and ${ }^{* * *}$ indicate statistical significance at the $10 \%$ and $1 \%$ levels, respectively.

\begin{tabular}{|c|c|c|c|c|c|}
\hline Dependent variable: & $\begin{array}{l}\text { \% Change in } \\
\text { firm's labor force } \\
\text { (Dec. 2007-Dec. } \\
\text { 2009) }\end{array}$ & $\begin{array}{l}\text { Indicator for } \\
\text { labor force } \\
\text { reduction (Dec. } \\
\text { 2007-Dec. 2009) }\end{array}$ & $\begin{array}{l}\text { In(total \# of } \\
\text { jobs posted, } \\
\text { Apr. 2008- } \\
\text { Dec. 2009) }\end{array}$ & $\begin{array}{l}\text { Indicator if } \\
\text { jobs posted } \\
\text { per month }> \\
0\end{array}$ & $\begin{array}{l}\ln (\# \text { of jobs } \\
\text { posted per } \\
\text { month) }\end{array}$ \\
\hline Maximum CDS price, 2008-2009 & 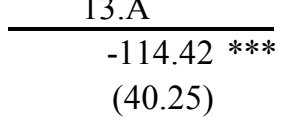 & $\begin{array}{c}13 . \mathrm{B} \\
1.96^{* * * *} \\
(0.60)\end{array}$ & 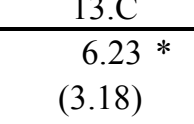 & 13.D & 13.E \\
\hline CDS price & & & & $\begin{array}{r}0.38 \\
(0.27)\end{array}$ & $\begin{array}{l}1.96 * \\
(1.14)\end{array}$ \\
\hline $\begin{array}{l}\text { Fixed effects } \\
\text { Firm } \\
\text { Month }\end{array}$ & & & & $\begin{array}{l}X \\
X\end{array}$ & $\begin{array}{l}X \\
X\end{array}$ \\
\hline $\begin{array}{l}R^{2} \\
N\end{array}$ & $\begin{array}{r}0.15 \\
38 \\
\end{array}$ & $\begin{array}{r}0.09 \\
38 \\
\end{array}$ & $\begin{array}{r}0.03 \\
40 \\
\end{array}$ & $\begin{array}{r}0.61 \\
836 \\
\end{array}$ & $\begin{array}{r}0.89 \\
686 \\
\end{array}$ \\
\hline
\end{tabular}

